\title{
GEM PEGMATITES OF MINAS GERAIS, BRAZIL: EXPLORATION, OCCURRENCE, AND AQUAMARINE DEPOSITS
}

\author{
By Keith Proctor
}

The northeastern portion of the state of Minas Gerais, Brazil, contains the world's greatest concentration of complex granitic pegmatites, which are especially noted for the production of gem beryl, chrysoberyl, topaz, tourmaline, and kunzite. Pegmatite gemstones were first found in this region over 400 years ago; in the last 100 years, Brazil has supplied most of the world market for these five gemstones. As the first of a series of articles on this region and these gem materials, this article reviews the early exploration for gemstones, their occurrence, and the mining methods and miners responsible for the development of the deposits. Focus is then given to some of the major deposits of aquamarine and other beryls, especially in the Teofilo Otoni-Marambaia and lequitinhonha River valley districts.

\section{ABOUT THE AUTHOR}

Mr. Proctor is president of Keith Proctor Fine Gems a wholesale gem import firm, in Colorado Springs, Colorado.

Acknowledgments: The author thanks the following people, only some of the many who helped with this article: for translating, $H$. Arosteguy, F. Bastos, $R$. Downes, R. McClellan, P. Neto, J. Uemura; for artwork and typing, Metta Marie Fife and Lyn Moffett; for reviewing and critiquing the original . manuscript, Drs. P. Bariand, R. Gaines, P. Keller, P. Moore, R. Nash, F. Pough, J. Shigley, and $J$. Sinkankas; and for their invaluable information and assistance, Dr. C. Barbosa, K. Elawar, H. F. Kennedy, A. Lucio, A. Sabbagh, J. Sauer, H. Stern and A. Tavares. Special appreciation goes to Mauna Proctor for her help in translating, lyping, and editing and for her constant support.

(C1984 Gemological Institute of America
М illions of carats of fine gem aquamarine, tourmafrom northeastern Minas Gerais in this century. Their source is the complex series of granitic pegmatites found throughout this $233,000 \mathrm{~km}^{2}(90,000 \mathrm{sq}$. mi.) region. Their chief producers were the colorful garimpeiros who extracted them from the thousands of diverse deposits in this region. The result is some of the most beautiful gems ever to appear in fine jewelry (figure 1).

This series of articles reviews the most important pegmatite deposits in this region for the five types of gemstones mentioned above (figure 2). Because of the enormous complexity of the area, the author has attempted to simplify the discussion by grouping the occurrences into districts. Although the districts are seldom as sharp as indicated on the map in figure 2, they do help manage this unwieldy subject.

The story of the gem pegmatite deposits of Minas Gerais begins over 400 years ago with the first expeditions into the interior of Brazil. This article continues with a discussion of early mining in the area, the geochemistry and geologic development of the pegmatite deposits, and the mining methods used in recent times. Following this introduction, the major deposits of aquamarine and other beryls are described, including associated minerals, major specimens produced, geologic occurrence, and production figures where available. Future articles in this series will deal with the major tourmaline, topaz, chrysoberyl, and kunzite deposits in this important region.

\section{HISTORY, OCCURRENCE, AND MINING}

\section{EARLY EXPLORATION AND MINING}

Brazil was discovered first by the Spaniard Vincente Pinyon in 1500 and then by Portuguese navigator Pedro Cabral that same year. Cabral was looking for spices, 


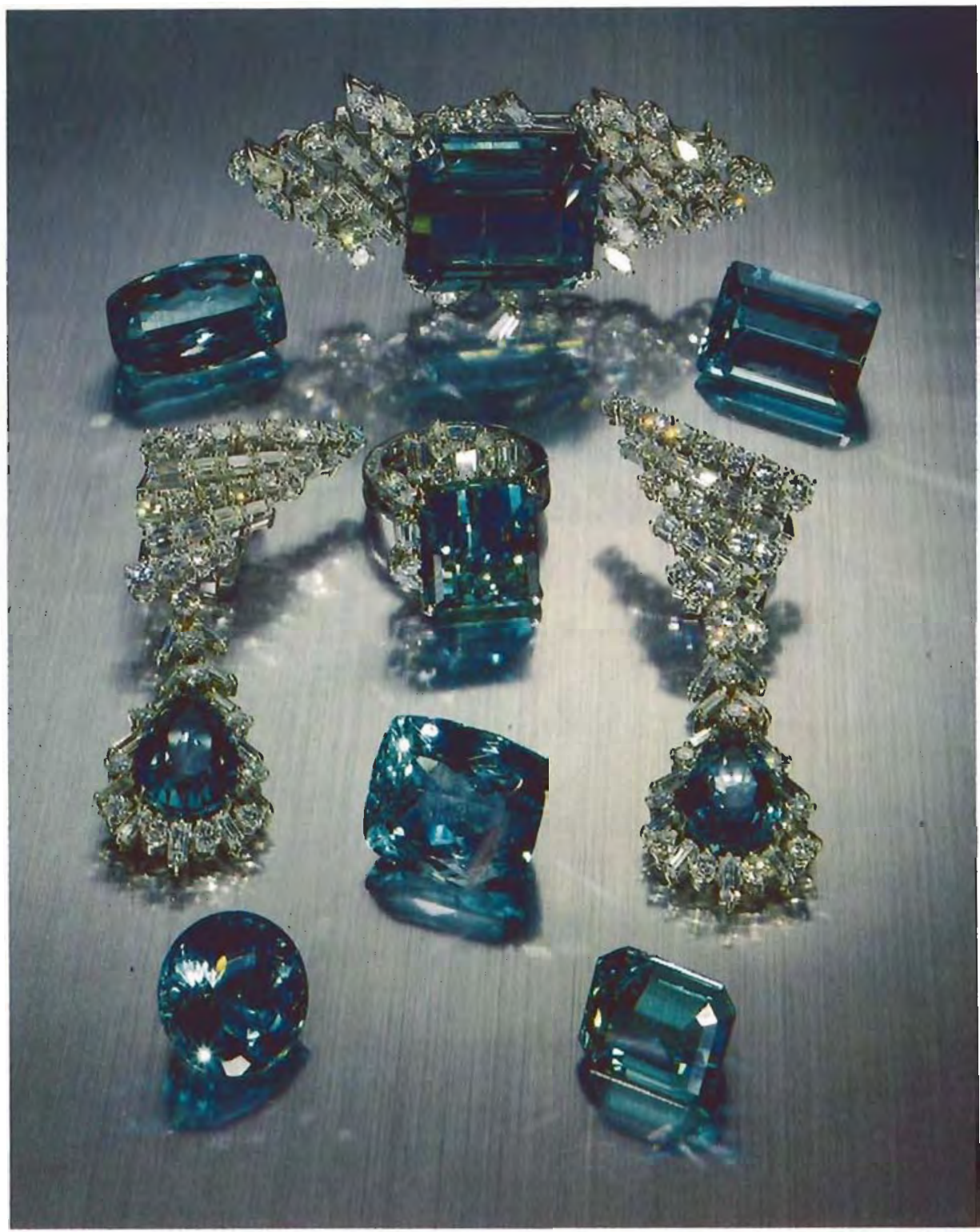

Figure 1. These stones represent the variety of fine aquamarines found throughout the Minas Gerais pegmatite region. The 54-ct stone in the brooch at the top of the photo is from the famous Marta Rocha crystal; the approximately 35-ct stone in the ring is from the Medina mine. Photo $(\mathrm{C}$ Harold est Erica Van Pelt; courtesy of Jules Sauer (Sauer, 1982). precious metals, and a route to the Far East for the Portuguese crown. He found none of these, and one of his pilots even reported in a letter, "It can be said, we found nothing profitable" (Lucio, 1980).

For the first 50 years, settlement and development were limited entirely to the coastal areas, where no gold or precious gems were to be found. Within this short time, however, the new colony became a major producer of sugar cane, dyes /from the Brasil tree), and timber. But the Portuguese crown was not satisfied with this wealth; frustrated at not having discovered gold, as the Spaniards had in the regions that are now Mexico and Peru, they pushed incessantly for the exploration of the vast interior territory to the west.
Letters written in 1500 by Pero Vaz de Caminha to King Manoel I made reference to the existence of gold and silver in the colony, but omitted proof of such discoveries (Burns, 1965). Although local Indians wore no ornaments of gold, they told stories of its existence deep within the interior. The Indians did wear "precious stones," and when they described a green gemstone commonly found inland, the Portuguese greedily assumed that it was emerald. They began to plan large expeditions to explore and colonize the interior (Ball, 1930; Bank, 1979; Zeitner, 1979; Lucio, 1980; Moura, 1981).

The major barrier to exploration was the range of mountains that borders much of the coast of 


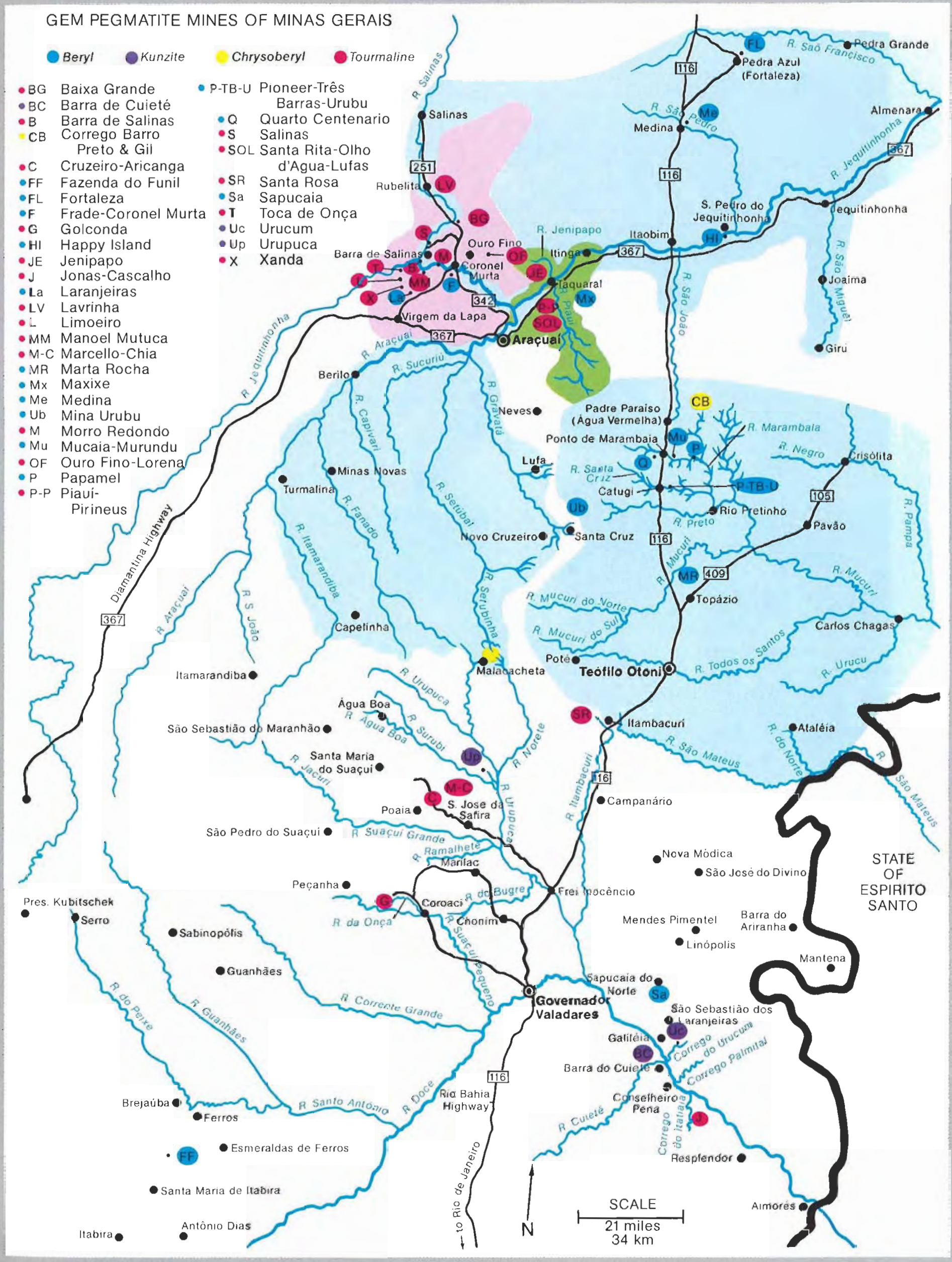


Figure 2. This map of the northeastern portion of Minas Gerais, Brazil, shows the major gem pegmatite deposits in this region. Three of the four major aquamarine districts discussed are shaded in blue here (for the broad Governador Valadares region, only cities near major deposits are noted). Two of the better-defined tourmaline districts are also shaded: red for the district that has produced many of the most important rubellite deposits; green for the one responsible for much of the finest green and blue tourmaline. Blue topaz, not shown on the map, was found to occur with tourmaline in the Limoeiro and Xanda mines. Colorless topaz, often treated to produce blue, is found over the entire Teofilo Otoni-Marambaia district. (Sources: Ferraz, 1929; Freyberg, 1934; Calmbach, 1938; Sinkankas, 1974, 1981; and field investigations of the author.)

Brazil; it was so heavily forested that passage was almost impossible. The area now called Minas Gerais (General Mines) could only be entered via the valleys of the six major rivers that drained the region. Portuguese pioneers made four large expeditions up. these river valleys in the years 1554, 1568,1571 , and 1674 (see figure 3).

The first expedition was led by Francisco Spinoza. His bandeirante group, so-called because of the banners the men carried on their horses, took a torturous route following the Jequitinhonha River to the region where the cities of Serro and Diamantina exist today (Calógeras, 1904; Abreu, 1937, 1965; Sousa, 1943; Paiva, 1946).

No emeralds or gold were found during this grueling three-year, $1,800-\mathrm{km}$ expedition, but it is highly likely that Spinoza's men brought back the world's first recorded gem tourmaline (Ball, 1930). In his book De Rerum Fossilium, published in 1565, Conrad Gesner provided a quaint woodcut of an elongated, striated crystal with a pointed termination which he called "Smaragdus Bresilicus cylindri specie" ("A cylindrical species of Brazilian emerald"). The appearance and description of this striated crystal indicate that in fact it was tourmaline (Sinkankas, 1974, 1981).

The second expedition (1568) was commanded by the explorer Martim de Carvalho after he was tempted by some "green stones" brought to Pôrto Seguro-the earliest seaport-by the Indians from the interior (Bastos, 1972, 1981; Moura, 1981). These were thought to be emeralds, like those reported from Colombia. Carvalho's bandeirante group also followed the Jequitinhonha River to the mountains of Itacambira. From there the bandeirantes proceeded southeast to what is now Minas Novas, where they discovered sands bearing gold nuggets (Moura, 1981). Carvalho also brought back "Brazilian emeralds," just like the crystals he had originally seen at Pôrto Seguro.

The green stones were shipped to Portugal, where they were cut and subsequently set in the crown of Nossa Senhora da Penha. Only after many years had passed were the "Brazilian emeralds" identified as green tourmalines (Bastos, 1972). Bank (1979) and Sinkankas (1974) point out that for over 300 years a number of gemological treatises continued to use the term Brazilian emerald for green tourmaline.

A third expedition, led by Fernandez Tourinho, departed in 1571 and traveled by way of the Doce River until they passed the site of the

Figure 3. The routes taken by the four major bandeirante groups that entered what is now the state of Minas Gerais in search of gemstones and precious metals between 1554 and 1674.

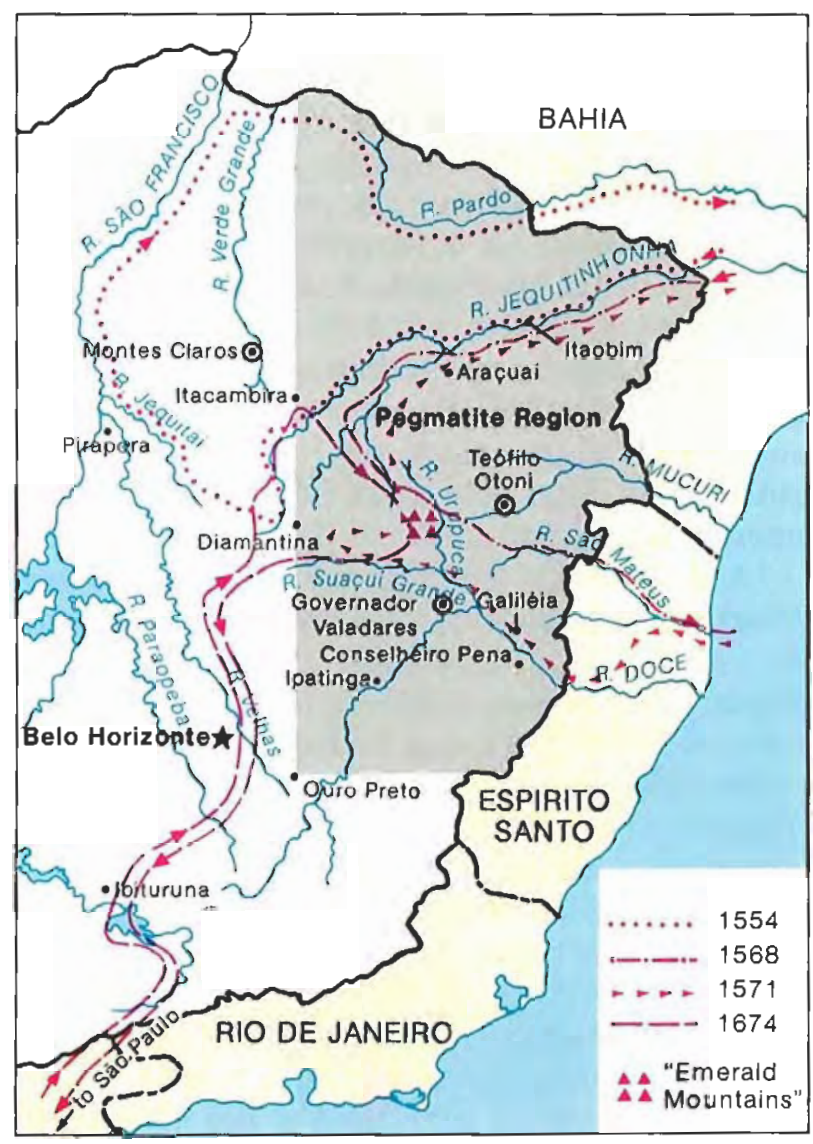


present-day gem center Governador Valadares. They then proceeded to the headwaters of the Suaçui Grande River, passing through the region of the future Cruzeiro and Golconda tourmaline mines. Turning north, the bandeirantes traversed three river valleys and entered the richest pegmatite region in Brazil, near the present town of Araçuar. They returned to the coast via the Jequitinhonha River, but not before discovering green and blue tourmaline and blue beryl crystals, which they incorrectly identified as emerald, sapphire, and turquoise, respectively (Eschwege, 1833; Moura, 1981).

In the early history of Brazilian mining, most gems were discovered during the process of testing alluvial (placer) gravels for gold, and Paiva (1946) gives Tourinho credit for being the first to find precious stones by this method.

A hundred years passed before the fourth and most famous of the bandeirante expeditions was organized and led by Fernão Dias Paes Leme to search for the fabled "land of emeralds." In a journey that began in São Paulo in 1674 and lasted almost seven years, he and his band of adventurers finally stumbled on to the famous "Emerald Mountains" (Bank, 1979; Lucio, 1980).

In the immediate vicinity of today's famous Cruzeiro mine and the village of São José da Safira |misnamed "sapphire" for the blue tourmaline found there), Paes Leme discovered the first recorded pegmatite-a mountain of mica with the green crystals of his dreams. Soon after his discovery, however, he was taken ill with malaria and died. Although he never found true emeraldsagain, the green crystals were tourmalines-it is ironic that Itabira, one of the hamlets his roving band settled, later became an important center of emerald production in Brazil (Lucio, 1980).

A total of 128 gems (about $430 \mathrm{~g}$ ), including "emerald," aquamarine, and topaz, found during the expedition were shipped to Lisbon in 1682 (Paiva, 1946; Moura, 1981). In 1698 another shipment of stones was sent to Portugal; and these stones, when examined by experts familiar with emeralds from India, were pronounced "worthless tourmaline" (Bastos, 1972; Bank, 1979).

These bandeirante expeditions, the longest of which lasted almost seven years and traversed a staggering $10,000 \mathrm{~km}(6,250 \mathrm{mi}$.), were responsible for opening Brazil's enormous interior. Innumerable hamlets along the river valleys were settled by expedition members who tired of the march and decided to take advantage of the free land. It is no accident that many years later, when the first mining would be done in alluvial deposits, these hamlets became the major gemstone mining centers. Two additional events produced waves of immigration that greatly accelerated exploration for gemstone deposits: the discoveries of gold near Ouro Preto in 1669 and of diamonds near Araçuar in 1721 (Sinkankas, 1974).

Paes Leme's discovery of gem-bearing pegmatites in 1676 was virtually ignored for almost 200 years because there was no significant market for Brazilian pegmatite gemstones. At the beginning of the 19th century, however, aquamarine and topaz were mined from near Ouro Preto; and in 1811, the first large aquamarine on record, a grass-green crystal weighing approximately $7 \mathrm{~kg}$ (15 lbs.) was found in the headwaters of the São Mateus River near Teófilo Otoni (Oakenfull, 1913; Calmbach, 1938; Moura, 1981). In Europe, much interest was aroused in Brazilian gems by London jeweler, lapidary, and mineralogist John Mawe, when he described a great variety of gemstones he had encountered during his travels in Brazil and offered to supply them on a regular basis (Mawe, 1812).

\section{MODERN DEVELOPMENTS}

The key factor in the modern development of gemstone mining in Brazil, however, was the colonization of large areas of southern Brazil by European immigrants starting around 1850 . In particular, many German families settled in the Teofilo Otoni area between 1860 and 1900 .

When shiny, transparent, colored crystals began to appear in the burrow excavations of armadillos and as a result of almost any kind of digging activity, the gem-conscious German immigrants immediately recognized the potential and sent some of the stones to the lapidary center of Idar-Oberstein for examination. Thus was forged a close relationship between Brazil and Germany with respect to gemstone mining and marketing that was to last for many decades to come (Rolff, 1968; Lucio, 1980; R. Nash, pers. comm.).

From the early 1900s onwards, Lebanese immigrants also established themselves in Teofilo Otoni, and the natural association of their traditional commercial skills with the industriousness of the Germans led to an enduring relationship. During the formative years of the Minas Gerais 
gem trade, the only foreign buyers were the Germans and one of the first local export firms was that of Abel Jacinto Ganem.

As early as 1902, a regular system of trading was established between Teofilo Otoni and Germany, with the rough being shipped via the newly completed railroad to Caravelas on the coast of the state of Bahia. Within a few years, German dealers began to make the arduous trek to the small hamlet of Teofilo Otoni. In 1907, Abel Jacinto Ganem and his partner, Feliciano Bamberg, established an office in Idar-Oberstein.

The first garimpos /a series of mining pits, or catras; a garimpeiro is a miner) were started around 1900, about $83 \mathrm{~km}$ north of Tebfilo Otoni in the Marambaia valley, which was known to be a plentiful source of aquamarine (Lucio, 1980). In late June 1910, a major gemstone discovery was made that was to have a profound and lasting effect on the development of gem mining in Minas Gerais. The largest and most famous gem aquamarine crystal found in this century, weighing $110.5 \mathrm{~kg}$ (244 lbs.) was unearthed at the Papamel mine on 'the Marambaia River, approximately 20 $\mathrm{km}$ east of the village of Ponto de Marambaia. This abraded and waterworn, doubly terminated, hexagonal prism measured $48.5 \mathrm{~cm}$ long $\times 38 \mathrm{~cm}$ in diameter $(19 \times 15 \mathrm{in}$.). The major portion was a fine blue-green. The crystal was flawless and so transparent that one could read print through it from end to end (Sinkankas, 1974, 1981).

The crystal was discovered by the Syrian Tanuri brothers, less than one meter below the bottom of a colluvial-alluvial pit that had just been abandoned in disgust by another miner (Dreher, 1912; Sinkankas, 1981). They sold it to two German gem dealers, August Klein and Viktor Bohrer-Borges, who happened to be in the area. George Kunz (1911) reported the purchase price as equivalent to US $\$ 25,000$ and accurately estimated that the crystal would produce $200,000 \mathrm{ct}$ of finished gems. August Klein then undertook a 20-day struggle to transport the massive crystal to the coast, hauling it first by mule $72 \mathrm{~km}$ through the jungle to the village of Araçuar, and then floating it by canoe down both the Araçuar and Jequitinhonha rivers to the coast. From there it traveled via coastal steamer to the city of Bahia (now Salvador), at which point a German steamer carried it to Germany (Hahn, 1955; Sinkankas, 1981).

After reaching Hamburg, Klein assumed the large wooden crate with its treasure would be shipped directly to Idar-Oberstein. Upon reaching Idar a few days later, however, he was shocked to find that the crystal had not yet arrived. He backtracked to Hamburg and found the crate, unidentified, sitting in the corner of a freight warehouse waiting for a claimant. This time he personally escorted the crystal to Idar-Oberstein, where the firm Bohrer-Borges took possession and offered it for sale for the equivalent of US $\$ 139,000$. When no museum or other institution stepped forward to buy the crystal in its entirety, it was cut up and the pieces sold individually (Hahn, 1955; Sinkankas, 1981). The American Museum of Natural History in New York City now displays the nearly 6-kg remnant (presumably the only uncut piece of the Papamel aquamarine) in the J. P. Morgan gem collection /Gaines, 1976; Anderson, 1978; photo in Sauer, 1982, p. 30|. It is interesting to note that the Papamel aquamarine is the first crystal on record to have been heat treated to obtain its optimum blue color (Bank, 1973). The current wholesale value of this piece has been estimated at close to US $\$ 25$ million (J. Sauer, pers. comm.)

News of the selling and asking prices for the Papamel crystal precipitated a sudden flurry of activity by Brazilian miners and German dealers alike. This enthusiasm stimulated the search for aquamarine and eventually contributed to the development of the entire central and northern portions of the Minas Gerais pegmatite region.

Aquamarine was popular in Europe even as early as 1910; the popularization of tourmaline came somewhat later, with the development of gemstone mining around the hamlets of Governador Valadares and Araçuar. At this time, German dealers could reach Governador Valadares, $145 \mathrm{~km}$ south of Teofilo Otoni, only by horseback along a narrow path cut in the jungle (Lucio, 1980; Caplan and Wilson, 1980).

In 1914, the deposit of green and blue tourmaline first discovered by Paes Leme in 1676 at Serra Resplandecente, near the present-day Cruzeiro mine, was rediscovered and mining was begun. Magnificent crystals were produced and used for cutting (Lucio, 1980).

In the early 1930 s, a garimpeiro named Barbosa discovered spectacular four- and five-color gem tourmalines at the Cascalho mine on the slopes of the Itatiaia mountain range near the town of Conselheiro Pena. These tourmalines, called papagaios (parrots) because of their brilliant 
colors, contributed greatly to the increased demand for tourmaline in Europe (R. de Vasconcelos and H. Bank, pers. comm.).

World War II provided the greatest stimulus to pegmatite exploration in Brazil. Beryl, mica, feldspar, quartz, and lithium minerals-mostly pegmatitic in origin-were needed in great quantities 1O'Leary, 1970; Sinkankas, 1974, 1981; Lucio, 1980). By 1950, the search for these strategic minerals had resulted in the discovery of several hundred gemstone mines (Gonsalves, 1949; Pecora, 1950), and this set the stage for the enormous increase in interest in Brazilian gems that followed the war. The city of Governador Valadares, the commercial hub for strategic minerals in the area, became second only to Teofilo Otoni as a gemstone center.

A major impetus to the development of these gemstone mines was that the sale of strategic minerals provided a basic income for the mine owners while the sale of gemstones provided a margin of profitability. For example, some gemstone mines in the Governador Valadares area pay for their entire operation just with sales of mica and feldspar.

Another vital source of income for gemstone miners developed starting in the late 1950s, when thousands of mineral collectors worldwide began buying rare gem crystals and even competed with museums for the best specimens (Sinkankas, 1974, 1981; Caplan and Wilson, 1980; Lucio, 1980). The sale of natural gem crystals and other rare pegmatite minerals kept many a mine operating during hard times. For example, the Jonas mine recently operated for 18 months on the money generated from the sale of tourmaline specimens.

\section{GEOLOGIC DEVELOPMENT OF THE PEGMATITE DEPOSITS}

The pegmatite region of the state of Minas Gerais is undoubtedly the finest laboratory in the world for the study of pegmatite gemology, because it contains the world's largest and richest concentration of gem-bearing pegmatite deposits. Extending approximately $320 \mathrm{~km}$ east to west and $720 \mathrm{~km}$ north to south, it is limited to the eastern and northeastern parts of the state (again, see figure 2). These deposits were created by a unique combination of geochemical, climatic, and other events that are briefly summarized below.

Formation of the Pegmatites. The reader is referred to the article by Shigley and Kampf in this issue for a general discussion of the formation of gem pegmatites. It is important to note again that although granitic pegmatites are extremely numerous worldwide, only a small percentage are gem bearing. Yet literally thousands of gem-bearing pegmatites are found in Minas Gerais. The granitic magmas responsible for the formation of these deposits were not only rich in the more common components of silicon, aluminum, iron, magnesium, potassium, sodium, and calcium, but also in the volatiles such as fluorine and chlorine, as well as such rarer elements as boron, lithium, beryllium, manganese, tin, niobium, tantalum, phosphorus, and the radioactive elements uranium and thorium (Cameron et al., 1949; Pough, 1969; Moore, 1973; Jahns, 1982). The availability of this diverse group of chemical elements resulted in the formation of thousands of gem pegmatite deposits in all stages of mineralogical complexity and containing virtually every gem pegmatite mineral species known (Sinkankas, 1974, 1981; Anderson, 1978). In most cases in Minas Gerais, the gem materials originated in pockets within the host pegmatite.

The events that carved the present landscape of Minas Gerais had their beginning so long ago that it is estimated that the surface geology we see today was actually formed at some depth (at least 3 $\mathrm{km}$ [2 $\mathrm{mi}$.] beneath the original surface before erosion took its tolll. The pegmatites themselves are estimated to be approximately 490 million years old (Dirac and Ebert, 1967; Cassedanne and Lowell, 1982). During this period, the older, or "basement," metamorphic rocks-schists, gneisses, and some quartzites - which covered much of the area, acted as a "roof" capping the upward movement of the molten granitic magmas. However, as the magmas pushed upward, the overlying basement rocks were fractured and the cooling pegmatitic magmas were injected into the systems of cracks, commonly in an approximate north-south direction (Bassett, 1967; Lucio, 1980). This material eventually solidified into the primary pegmatite deposit, in which the pegmatite body is still enclosed in the original schistose or gneissic host rocks. Depending on local erosion and weathering, as explained below, such deposits exist today in various stages of decomposition.

During the same geologic time period, large masses of granitic magma also intruded the fractured metamorphic rocks vertically and eventually solidified as rounded or hump-like forms. 


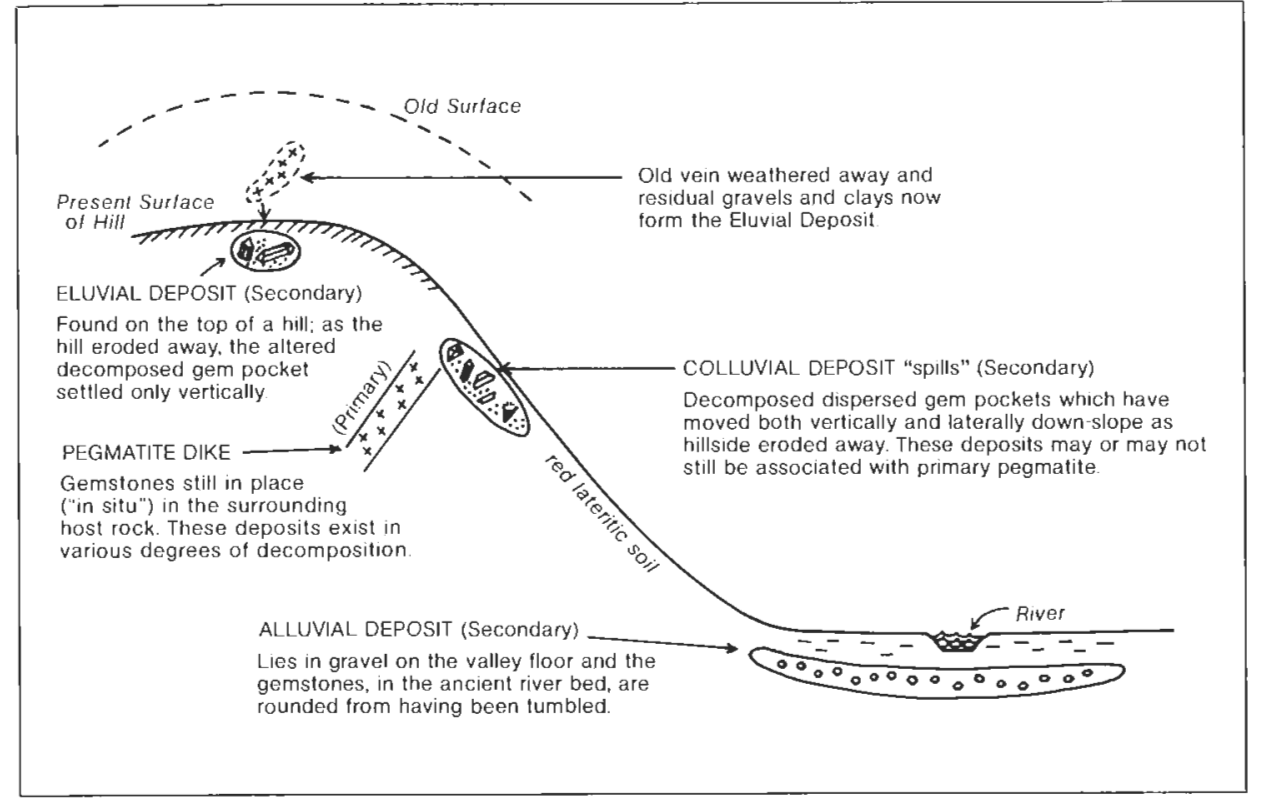

Figure 4. Diagram of primary (pegmatite dike) and secondary (eluvial, colluvial, and alluvial) deposits. All three secondary deposits have traveled some distance from their original primary pegmatite.
They were subsequently exposed by erosion to form the peculiar domed hills and mountains known by the German word inselbergs (island mountains) that are common in many parts of Brazil (the 'mountain known as "Sugar Loaf," in Rio de Jan'eiro harbor, is a perfect example). Hundreds of these tall, deeply grooved, forest-topped batholiths, commonly found in the immediate vicinity of gem pegmatite deposits, are the most prominent physiographic features of the pegmatite region of Minas Gerais. These domes represent the hardened "backbones" of the granite intrusions, and their presence today is evidence that most of the metamorphic "capping rocks" have long since eroded away (Dana, 1959; Rolff, 1968; Pough, 1969; Jahns, 1982).

Formation of Secondary Deposits. Weathering. As a result of extensive uplift and the erosion typical of a tropical climate and monsoonal conditions, the once-buried schists and gneisses, studded with pegmatite dikes, eventually became exposed on the surface as "hills," hundreds of meters higher than their present level. Subsequently, this "new" surface was again subjected to erosion; the exposed pegmatites weathered away along with the rest of the hill and shed their treasures on its slopes. The sands, clays, gravels, and loose gemstones now found blanketing the valley floors, and the red lateritic (clay-like) soil found on the slopes, are the residues of hillside erosion and contain the decomposed and dispersed contents of pegmatites (Sinkankas, 1964, 1974).
A distinctive feature of this entire region is the deep chemical weathering of the pegmatite bodies brought about by the soil conditions and the monsoon-like rains that make mining all but impossible from October through February. In many hillside deposits, the pegmatites are commonly altered and decomposed to depths of $50 \mathrm{~m}$ or more. Since pegmatite bodies are generally not large, frequently the weathered zone extends far beneath the pegmatite itself (Bassett, 1967; Sinkankas, 1974; Lucio, 1980). The contents of gem pockets are also chemically altered, with some of their constituents being broken down into secondary alteration minerals such as clays (Jahns, 1982). Generally, only the gem minerals survive; even the feldspar crystals eventually succumb to the attacks of water, air, carbon dioxide (carbonic acid), and soil (humic) acids, and alter to crumbly white clays principally composed of kaolin. The more resistant minerals, such as quartz, beryl, tourmaline, and topaz, survive and are found intact in the "softened" decomposed pocket.

Miners consider the white kaolin a sign that they may be close to gem-bearing pockets. Another indication is the occurrence of pocket residues such as fine muscovite mica flakes in the soil and, better still, clear or smoky quartz crystals with sharp faces. Once they reach such an altered deposit, they look for scattered and detached gem crystals lying loose in the clay.

Types of Secondary Deposits. In Minas Gerais, then, gemstones are found not just in pockets in 
the primary pegmatite deposit but also (and more commonly) in one of three types of secondary deposits-eluvial, colluvial, and alluvial (figure 4). The secondary deposits are those that result from the complete decay of a gem-bearing pegmatite body with consequent release of its resistant minerals into the soil. In these three types of secondary deposits, gemstones have all traveled some distance from their original pegmatite. Eluvial deposits commonly occur on hilltops; as the hill is eroded, the decomposed pocket material moved directly downward from the original pegmatite. Colluvial deposits are pegmatite materials that moved both downward from and lateral to the pegmatite as the pegmatite and its enclosing rocks eroded; a colluvial deposit may or may not be closely associated with its parent pegmatite. Sometimes the pocket material is found as a "spill" of gem crystals in the red lateritic soil below the pegmatite outcrop. A tex tbook example of this deposit type is the Frade aquamarine mine near Coronel Murta, discussed later in this article; in this case, the resistant pocket crystals are still closely associated with the parent body. Lastly there are the alluvial deposits, which are always found in the valley floors and which contain rounded, waterworn stones and gemstones that represent gravels of a former or still-existing riverbed. The condition of the gem material itself usually reflects the distance it has traveled from the original pegmatite. Those specimens found closer to the primary source have sharper crystal faces and are less damaged than those found farther away (i.e., crystals found in the pocket itself are usually sharper than those found in the eluvial or colluvial deposits, which in turn are less damaged than those found in the alluvium). Interestingly, however, although gemstones found in the alluvium are usually smaller and more rounded, the material itself is much cleaner, since flawed crystals erode more easily /see the discussion of the Três Barras aquamarine deposits later in this article). The exception to this general rule is seen in the Frade aquamarine mine, where even crystals found in the primary pegmatite are highly fractured. This is apparently the result of decompression explosion and consequent thermal shock during late-stage pocket formation (see Shigley and Kampf, 1984).

\section{MINING METHODS}

Hard-Rock Mining (Primary Deposits). When a primary deposit is discovered with the pegmatite and its host rock (schist or gneiss) still unaltered, bulldozers, explosives, drills, and other types of heavy equipment are required to mine the gemstones (figure 5). These deposits are often the richest and most productive (e.g., the Jonas mine) because their contents have not yet been altered or dispersed. The government grants mining concessions (registered claims) for such operations because of the great expense involved; today there are only a few-perhaps 30-of these concessions in Minas Gerais (Lucio, 1980).

For the most part, the hard-rock mining methods used in Minas Gerais are simple. Miners drill, place dynamite charges, blast, and then clear away the rubble by hand or with some type of earth mover. However, even in such mechanized operations, the miners still resort to hand sorting when they reach the gem-bearing pockets.

Soft-Rock Mining (Secondary Deposits). Historically, most of the mining of pegmatite minerals has taken place in the altered and dispersed secondary deposits that occur by the thousands in Minas Gerais. Because of the softness of the earth and the fact that the rock has decomposed, only the most basic tools-pick, shovel, and sorting basket-are needed to free the gemstones (figure 6). Many of the pits were started even before the turn of the century, when the garimpeiros, or miners, could not make a living in agriculture or other pursuits. The garimpeiro, usually alone and almost always independent, has been a major factor in Brazil's preeminence as a gemstone producer for close to 100 years.

\section{THE GARIMPEIRO: KEY TO THE PAST, QUESTION MARK FOR THE FUTURE}

By federal law, the mineral deposits belong to the government, and any licensed garimpeiro may work unprohibited on any state-owned lands where gems and minerals have been found /and also on many private lands, with the prior consent of the owner). The only exceptions are the registered claims granted as concessions. However, the garimpeiro must pay a $10-50 \%$ commission to the landowner on all gemstones found, with the exact amount determined by how much equipment and food, if any, the landowner gives the garimpeiro as his "grubstake." Only occasionally is the landowner compensated for the damage done to his property.

The garimpeiro labor force is largely landless, rootless, and illiterate, but also free and independ- 


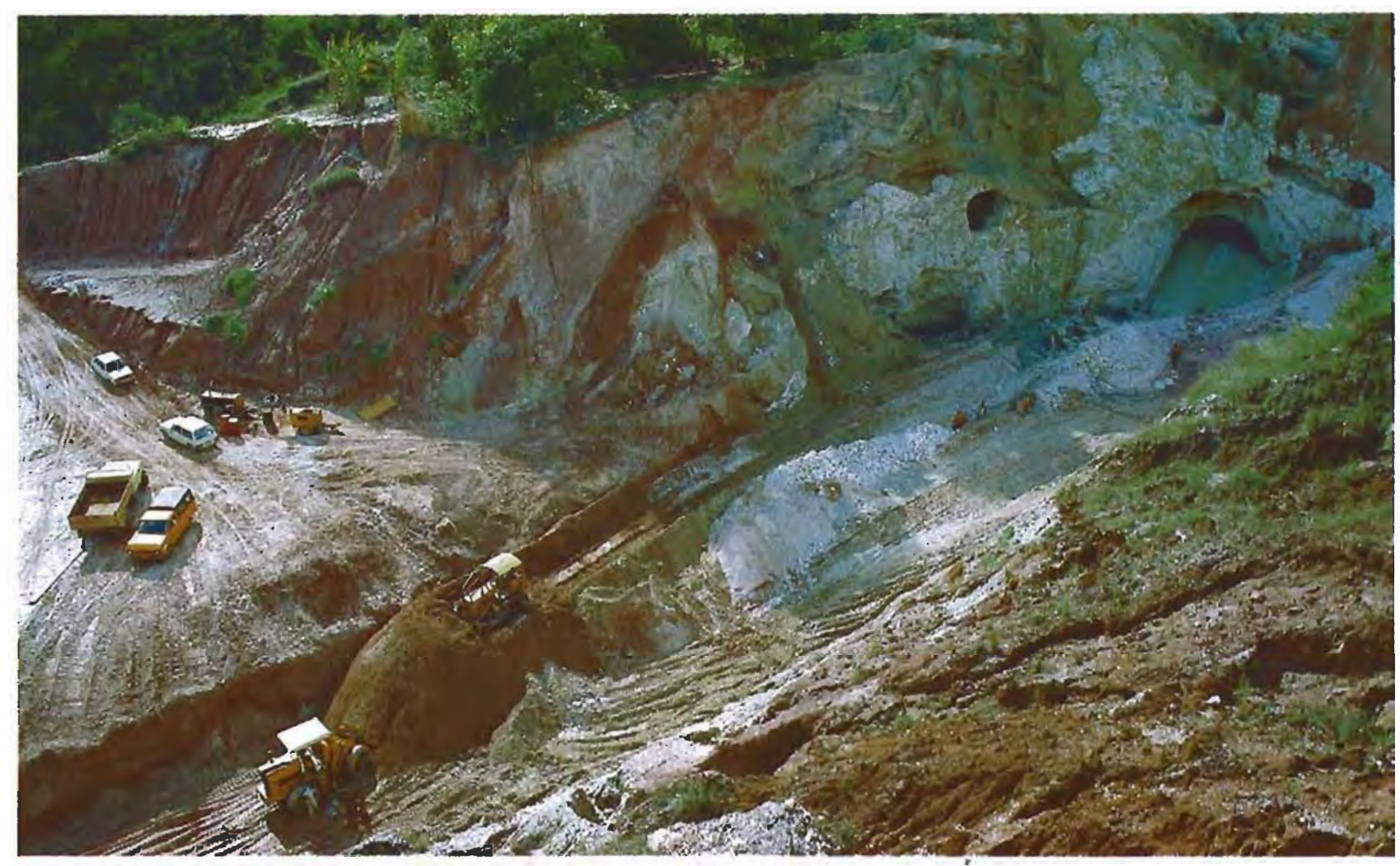

Figure 5. Heavy machinery is often required for hard-rock mining in Brazil. At the Golconda tourmaline mine, bulldozers are used to move the overburden and waste from the mine entrance.

ent and ready to move whenever a "bigger" bonanza beckons from over the next hillside. At the earliest word of a new, more promising find, often a veritable army of garimpeiros-many with their entire families-will pick up and leave. At each new area, the garimpeiro stakes out a few square meters of land for his private pit, his rights protected by an unwritten but rarely broken code. Large, sprawling temporary villages of shanties lacking utilities or sanitation have been known to spring up overnight.

Since 1970, however, several events have combined to make the garimpeiro almost an endangered species. During the past 15 years, about $90 \%$ of the garimpeiro mining force has left pegmatite mining to obtain steady employment in industry, agriculture, and gold mining.

Because of the lack of coal in Brazil and the high cost of its importation, steel companies around Itabira have been forced to buy land and plant millions of fast-growing eucalyptus trees, eventually to be burned into charcoal for use as a reducing agent for iron ore in the production of steel. Both the reforestation projects and the burning of the wood into charcoal are labor-intensive pursuits and now employ thousands of former or potential garimpeiros (Lucio, 1980).
Figure 6. Pick and shovel are the basic tools of the garimpeiro searching for aquamarine crystals in the "soft rock" of this colluvial pit near the bottom of Frade valley.

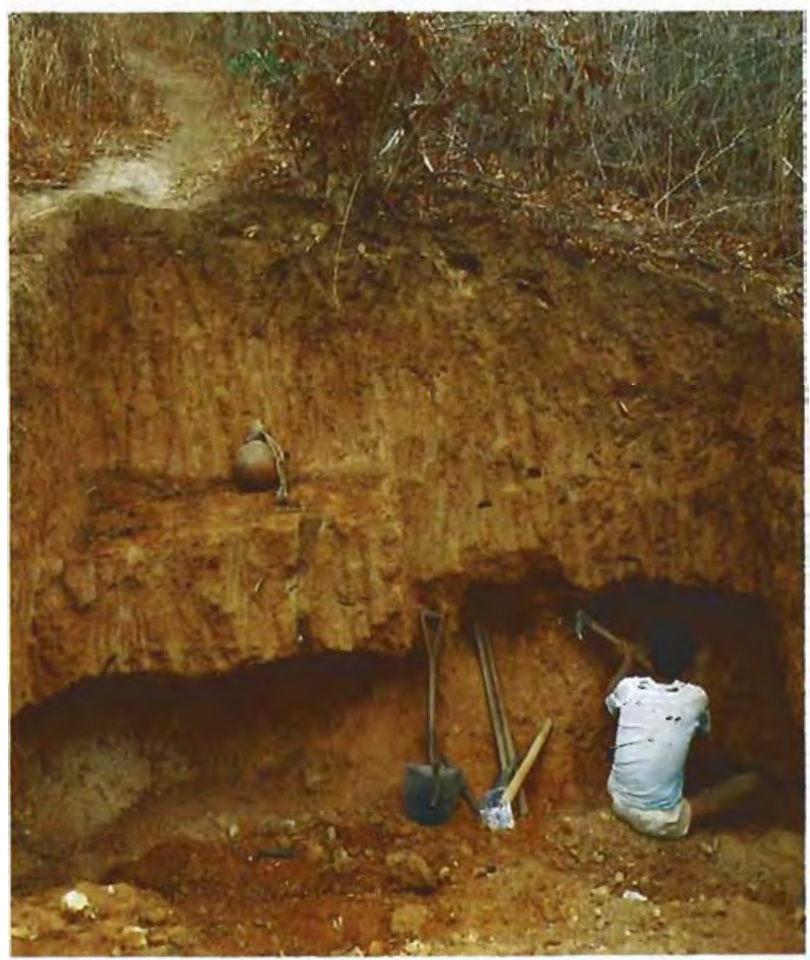




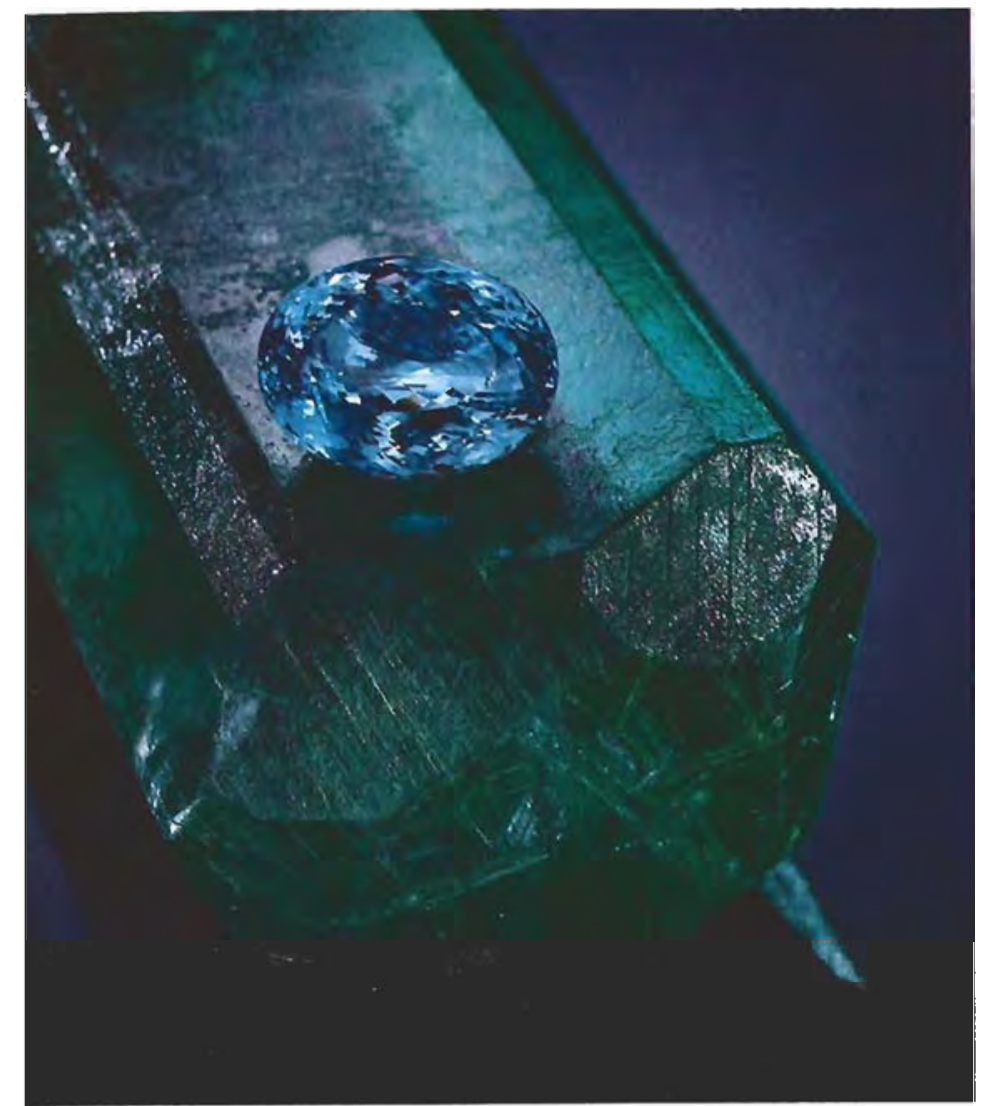

Figure 7. This 40-ct faceted aquamarine sitting on the 898-g "Pioneer" aquamarine crystal represents the color that would result if the natural crystal were cut and the stones heat treated, the standard practice with aquamarine worldwide. Photo (C) Harold e Erica Van Pelt.

In addition, government-financed coffee plantations have sprung up all over the region. By 1980, 28 million coffee trees had been planted in the Teofilo Otoni region alone, providing jobs for six to eight thousand former garimpeiros. Also, land under plantations or in reforestation projects is lost to gem mining. The entire hillside known as the Lavra José de Sousa (lavra means workings), at the famed Três Barras aquamarine deposit, is now covered with coffee trees (Lucio, 1980; Sauer, 1982).

Lastly, gold mining offers a more certain source of income. Thousands of garimpeiros have been lured away to work at just one gold mine, the Serra Pelada, in the northern state of Pará; 45,000 miners work in a single huge pit. This, and other, gold-mining ventures are likely to go on for decades (C. Barbosa and R. Nash, pers. comm.)

All of these events have given the descendants of the gem-mining garimpeiros a whole new set of job options. Many have chosen the security of a steady wage rather than the uncertainty of the garimpos their parents mined.

The labor shortage and the depletion of the most easily accessible secondary deposits dictates that in the future the great majority of gemstone mining in Minas Gerais will have to be done on primary pegmatites using more expensive mechanized means (Sinkankas, 1974, 1981; Lucio, 1980 . To produce any kind of volume, even the mining of "softened" secondary deposits will require mechanization. This situation suggests that fewer gems will be produced - at even greater production costs.

The unique history and geology of the gem pegmatite region of Minas Gerais forms the basis for the discussion of specific beryl, chrysoberyl, topaz, tourmaline, and kunzite deposits that follow. The beryl (primarily aquamarine) deposits of northeast Minas Gerais are the focus of the next section presented here; the other gem materials will be covered in future articles.

\section{AQUAMARINE AND OTHER BERYLS}

Virtually all varieties of gem beryl are found in Minas Gerais, and all except emerald are of pegmatitic origin. While heliodor (yellow or golden beryl) and morganite (the pink variety) are found in small quantities in some localities, by far the most important pegmatitic beryl in Minas Gerais is aquamarine. Since the discovery of the Papamel crystal in 1910, several other major crystals and millions of carats of fine aquamarine have been mined from the thousands of deposits that dot the region.

Four districts in Minas Gerais have produced major amounts of aquamarine: (1) Teofilo Otoni-Marambaia, (2) Jequitinhonha River valley, (3) Araçuaí River-Capelinha-Malacacheta, and (4) Governador Valadares (see figure 2).

The following discussion will examine the important aquamarine deposits in the first two areas, many of which the author visited in 1983, in terms of their location and access, history and production, and the important mines and major specimens found there. Please keep in mind while reading the discussion and viewing the accompanying photographs that most aquamarine has a strong yellow component and thus appears green when viewed right out of the mine. It is generally heat treated to remove this yellow component to produce its optimum blue color (figure 7). Virtually all aquamarine is heated in this manner; the process duplicates one that commonly occurs in nature and the resulting color is stable. Depending 
on the mine the crystals come from and the clarity of the rough, finished stones are heat treated to between approximately $250^{\circ} \mathrm{C}$ and $720^{\circ} \mathrm{C}$ for a varying length of time (e.g., a stone with some inclusions will be heated at a lower temperature for a greater number of hours). Less than $5 \%$ of the aquamarines produced in this region yield topquality, dark blue stones (figure 8).

This section will also review the production of heliodor and morganite in this area. While large amounts of emerald have been mined in Minas Gerais, they will not be discussed here because most deposits are not found in association with pegmatites.

\section{TEÓFILO OTONI - MARAMBAIA PEGMATITE DISTRICT}

The Teofilo Otoni-Marambaia pegmatite district is now easily accessible from Teofilo. Otoni by

Figure 8. These aquamarines from the Mucuri River region (within the Teofilo Otoni-Marambaia pegmatite district) represent some of the best color produced in Minas Gerais. The stones range in weight from 18 to $35 \mathrm{ct}$. Photo (C) Harold et) Erica Van Pelt; courtesy of Jules Sauer (Sauer, 1982).

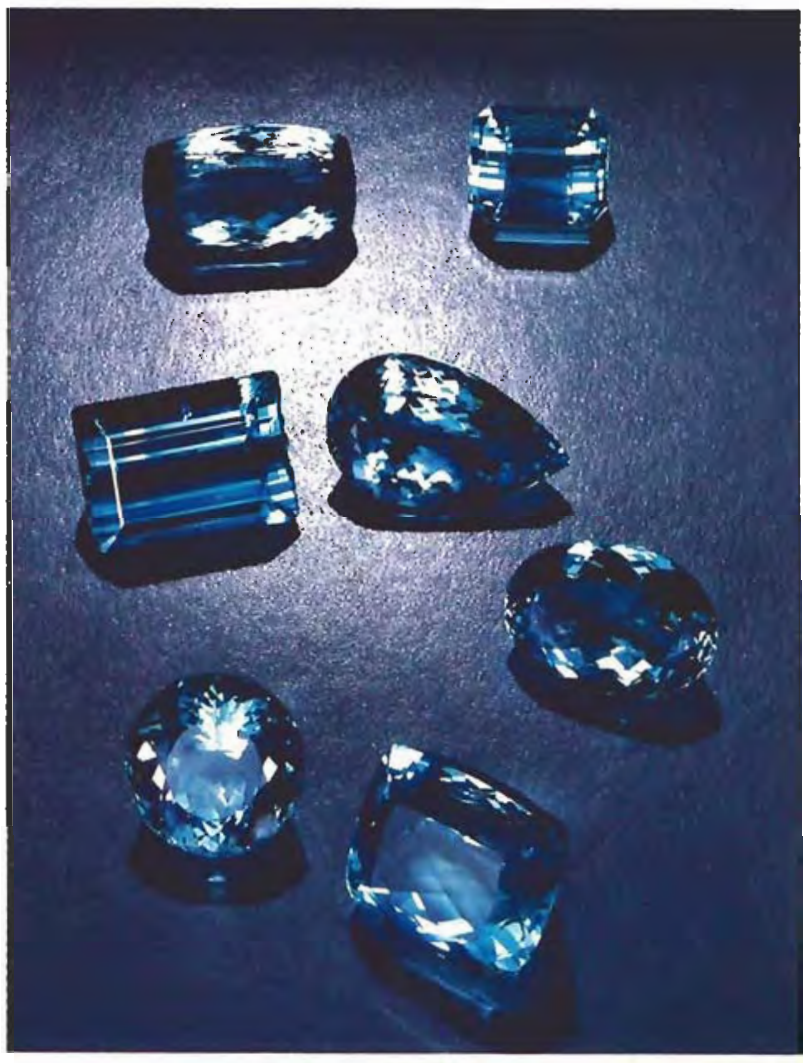

traveling on highway BR-116 north toward Itaobim. Although scattered aquamarine deposits exist farther south near Teoffilo Otoni at Ataleia and Itambacuri-and extensively along the Mucuri, Urucu, and Mateus rivers - the great preponderance of pegmatite deposits in this district is concentrated in an oval area encompassing a region roughly $50 \mathrm{~km}$ north, south, and west of the village of Catugi and extending east beyond the village of Crisólita to include the Pampã River valley (see figure 2).

This region, dominated by relatively quartzpoor, coarse-grained gneisses, is perhaps geochemically the most distinct pegmatite district in all of Minas Gerais. There are no schists. The pegmatite magmas in this district were rich in silicon, beryllium, aluminum, fluorine, and boron. All varieties of beryl except morganite are found here, as are relatively large deposits of chrysoberyl and alexandrite. Cassiterite and columbite also occur.

Topaz and aquamarine often occur in the same pegmatite deposit, but never in the same pocket. In secondary deposits, of course, beryl and topaz are often found together.

Black tourmaline is common in this region, but there are no lithium minerals, no colored tourmalines, and no known occurrences of morganite. Smoky quartz, citrine, and noncommercial amethyst are also common.

This district is noted particularly for the size of the aquamarines found there and the cut stones produced (probably the largest is the 911-ct stone in the Smithsonian Institution, Washington, D.C., illustrated on p. 90 of Desautels, 1970|. The most important aquamarine finds in this district have been principally in secondary (eluvial, colluvial, and alluvial) deposits in three major areas: the Topázio-Pavão-Crisolita valleys, source of the 34.7-kg (76-lb.) Marta Rocha crystal; the Marambaia valley, where the Papamel aquamarine was found early in this century and then the $22-\mathrm{kg}$ (48-1b.) Quarto Centenario in 1964; and the Três Barras valley, origin of the 19.2-kg (42-lb.) Estrela de Alva (Dawn Star) crystal.

Topázio-Pavão-Crisólita Valleys. The valleys and basins surrounding the three villages Topázio, Pavão, and Crisolita are easily accessible via highways BR-116 and MG-409 (see figure 2). These basins are part of the watershed of the Mucuri, Preto, Negro, and Pampã rivers. The abundance of aquamarine in this area led to the sinking of tens of 
thousands of pits in secondary deposits and many tunnels in primary pegmatites since prospecting was first begun in 1908 (Sinkankas, 1981). These have consistently produced large quantities of aquamarine. In fact, one of the most important aquamarines ever discovered in Brazil, the Marta Rocha, was found in this region.

After the 1910 discovery of the Papamel aquamarine, it became the dream of every garimpeiro to find a great crystal of his own to ensure lifetime fame and security. In July 1954, this dream came true for the garimpeiro Wilson Martins da Silva and the 12 miners he led and helped finance. Digging in the red soil in the side of a hill only $100 \mathrm{~m}$ high, they unearthed the second most valuable aquamarine crystal found in this century. This garimpo, the Lavra de Clemente Francisco, was located $6 \mathrm{~km}$ northeast of the village of Topázio, only $200 \mathrm{~m}$ west of the Pavão road.

Jules Sauer, the prominent Rio de Janeiro jeweler, was in Teofilo Otoni that morning when he got word of the find. He arrived at the mine barely two hours after the discovery, and quickly negotiated the purchase. This $34.7-\mathrm{kg}$ rounded prism, with superb, uniform color throughout, eventually yielded 57,200 ct of finished gems. A 54-ct stone cut from this crystal appears in the brooch illustrated in figure 1.

Judging by its rounded and battered condition, the aquamarine appeared to be river-rolled, that is, alluvial in origin. But one cannot establish that origin with certainty because a stone can become extremely worn in a colluvial environment when mixed with abundant and large blocks of quartz, as is often the case with aquamarine, which usually occurs in pockets adjacent to or near the quartz core of the pegmatite.

Before it was cut, this stone was appropriately named after a beautiful woman, Marta Rocha, Miss Brazil of 1954. To this day, the subject of superb cut aquamarines doesn't come up in Brazil without mention of Marta Rocha. Some stones from this material can still be found, but they are dearly held and carry a premium (Bastos, 1964; Abreu, 1965).

The discovery of the Marta Rocha aquamarine triggered another "rush," and thousands of garimpeiros overran the hillside and valley below, completely devastating the area. Land damage was so extensive that the farmer who owned the land had to move his cows off the property because there was nothing left for them to graze on-only bare earth and abandoned pits. Sauer (pers. comm.) estimated that six million man-hours were wasted by the garimpeiros over the next 12 months, and not one additional aquamarine was found.

Marambaia Valley. The Marambaia River valley lies perpendicular to the asphalt road $83 \mathrm{~km} / 52$ mi.) north of Teofilo Otoni at the hamlet of Ponto de Marambaia. Traveling $20 \mathrm{~km}$ east of the asphalt road on a good dirt road, you reach the Papamel mine, the source in 1910 of the first great aquamarine find.

During the 70 years following the discovery of the Papamel, thousands of kilos of aquamarines were removed from some primary and mostly secondary deposits over the entire length of the valley. In 1958, two major colluvial deposits were discovered on hillsides overlooking the diggings. At Murundu, $22 \mathrm{~kg}$ of crystals were removed. Then, at Mucaia (figure 9), Clementa Fell de Sousa, his son Zeca, and fellow garimpeiros found $520 \mathrm{~kg}$ of pale blue aquamarine. In a matter of weeks, over 2,000 garimpeiros descended on the hill. Eventually so much fighting erupted over digging sites that the military police had to be called in. In 1968, a few hundred meters from the original find at Mucaia, $165 \mathrm{~kg}$ of aquamarine were unearthed, with the largest crystal (medium blue) weighing 36 $\mathrm{kg}$. And in 1978, an 18-year-old garimpeiro found an exceptional $3.9-\mathrm{kg}$ prism in the Filipe valley below the Mucaia hilltop; this aquamarine eventually yielded $10,000 \mathrm{ct}$ of superior stones (A. Tavares, pers. comm.).

Another bomba (major find) was unearthed on May 20, 1964. Five $\mathrm{km}$ west of the highway and the hamlet of Ponto de Marambaia, a garimpeiro discovered four pieces of a crystal that produced some of the highest quality, darkest blue aquamarine ever recorded. The four pieces that comprised this etched and abraded, doubly terminated crystal were found by Abelo Ferreira in red lateritic soil more than $6 \mathrm{~m}$ under the top of a hill at the Pine Tree (Pinheiro) mine (Bastos, 1964; A. Tavares, pers. comm.). Less than $2 \mathrm{~kg}$ of additional small stones were found by Ferreira in this classic eluvial deposit.

This material was said to have the color of fine blue tourmaline (Sinkankas, 1974, 1981). When the nearly cylindrical crystal was reconstructed, it measured $68.5 \times 10.9 \mathrm{~cm}(27 \times 4.3 \mathrm{in}$.$) and weighed$ $22 \mathrm{~kg}$; it was almost entirely clean.

Agenor Tavares, a well-known Teofilo Otoni 
Figure 9. Alluvial diggings run the full length of the Marambaia valley on the low residual hills overlooking Marambaia Creek. At the height of production, 2,000 miners worked the hillside diggings at Mucaia. This topography is typical of the entire Teofilo Otoni-Marambaia pegmatite district.

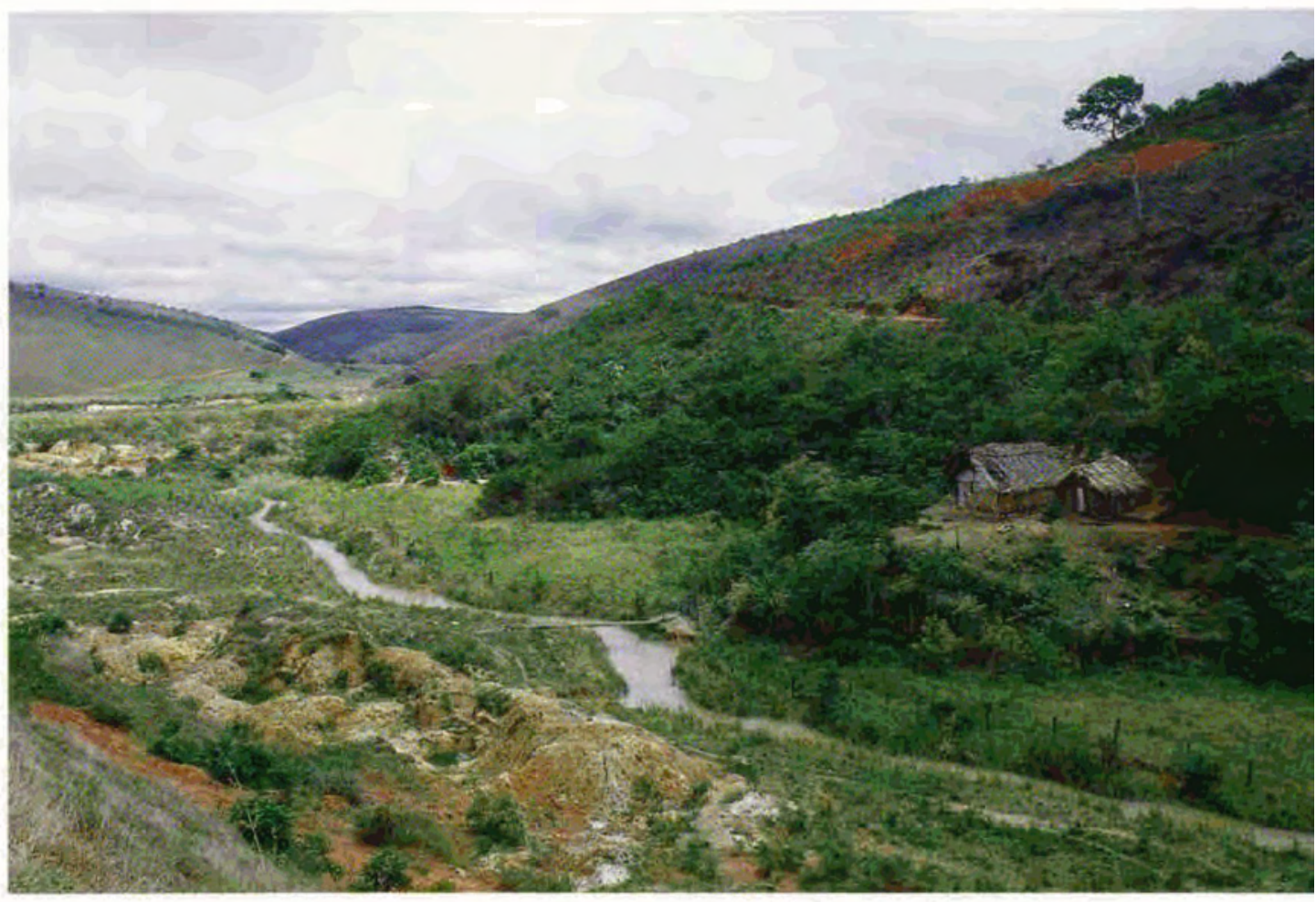

gem dealer, was living in nearby Padre Paraìso (formerly Aqua Vermelha) when he heard the exciting news. The first dealer to arrive at the site, he purchased the four pieces of the crystal directly from Ferreira for one hundred million cruzeiros (roughly US\$45,000 at that time). Although the price he received was enormous for the garimpeiro and very small given the thousands of carats of faceted stones it would produce), Ferreira's dream did not end happily. He quickly started on an extended celebration spree - and died two years later, totally destitute.

The three darker pieces of this aquamarine were sold to Abdul Millah and João Pessoa. The fourth piece, weighing over $7 \mathrm{~kg}$, was sold to the firm H. Stern in Rio de Janeiro. This lighter colored piece was the first to receive the name IV (Quarto) Centenario to commemorate Rio de Janeiro's 400 th anniversary. This piece was cut into 15,000 ct of medium-quality aquamarine (A. Tavares and H. Stern, pers. comm.). The stones cut from the other three pieces - all of which were much darker than the first-are also referred to as Quarto Centenario and are actually responsible for the reputation of this famous crystal.

Agenor Tavares later obtained the mining rights to the Pine Tree mine; using heavy bulldozers, he spent six full months looking for additional aquamarines. Deep in the red earth he even- tually hit a pegmatite, but it produced only $5 \mathrm{~kg}$ of aquamarine plus colorless topaz and some citrine. As with the Marta Rocha, the location yielded no additional bonanza of aquamarine. These two famous crystals graphically illustrate the frustrations of gemstone mining in Brazil: the only thing consistent about such discoveries is their inconsistency. Although of different hues, these two crystals are both touchstones by which the highest quality aquamarines are measured.

Três Barras Valley. The Três Barras (Santa Cruz River) valley lies south and runs roughly parallel to the Marambaia valley; it crosses highway BR-116 at the village of Catugi (formerly called Três Barras).

The first garimpos were started in the 1930s amid great activity at Pont Alete, $6.5 \mathrm{~km}$ south of the village of Três Barras. In 1967 and 1968, some of the largest aquamarine deposits ever found anywhere were mined in this valley and the surrounding low-lying residual hills. At the height of production, many aquamarines were found $1 \mathrm{~km}$ west of highway BR-116, just west of Catugi, but most of the famous Três Barras production was found east of the highway.

The Pioneer (Pioneira) Mine and the Dawn Star Aquamarine. On October 10, 1967, $5 \mathrm{~km}$ south- 


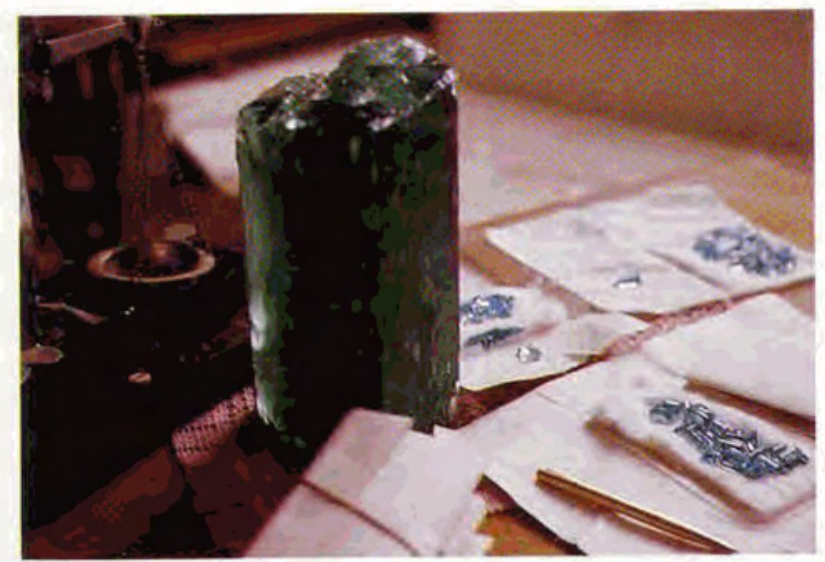

Figure 10. One-fourth of the Dawn Star crystal (originally $1 \mathrm{~m}$ long $\times 18 \mathrm{~cm}$ in diameter) and some of the stones cut and heat treated from other sections of the same piece. This photo, by Richard Gaines, was taken in Teofilo Otoni in late 1967.

east of Catugi and highway BR-116, a government bulldozer was carving a road up to the top of a hill where a microwave relay station was being built near a Sugar Loaf-like prominence. Near the top of the hill, the blade of the bulldozer rolled a large aquamarine crystal out from its hiding place onto the side of the road, where it lay unobserved by the bulldozer operator. However, seven men who had unsuccessfully sought employment at the microwave tower passed the bulldozer on their way back to Catugi, and as they stopped to examine the cut in the side of the hill, they found the $19.2-\mathrm{kg}$ aquamarine. Ecstatic over their discovery, they took turns carrying their treasure back to the village of Catugi. One of the first gem dealers contacted was the same Agenor Tavares of Quarto Centenario fame. Tavares rushed northward and again managed to arrive before the multitude of dealers who soon followed. He made his deal with the leader of the group, Zeferino dos Santos, and agreed to buy the stone for the equivalent of US\$30,000. The I.O.U. was scribbled on the paper liner from a pack of cigarettes. Eventually, Tavares decided to share the stone (and his indebtedness) with three other dealers. It was subsequently named the Estrela de Alva, or "Dawn Star." The crystal was almost $100 \%$ gem clean (figure 10): Mr. Tavares's 26\% portion cut 8,017 ct of fine gems (A. Tavares, pers. comm.; Gaines, 1976).

The source of this stunning crystal became the Pioneer mine, which proved to be what was probably the greatest deposit of fine-quality aquama- rine crystals in history. This small mine-a series of eluvial pits unrelated to any primary pegmatite body-produced over $1,500 \mathrm{~kg}$ of superior aquamarine crystals.

According to extensive research done by the author, all of these aquamarine crystals, with the exception of the 4,500-ct specimen pictured on the cover and in figure 7, were destroyed by cutting - a tremendous aesthetic and scientific loss. This specimen, which was dug by Colatino Ferreira, survived only because it passed through a series of crystal collectors rather than cutters.

Figure 11. This hillside at the Jose de Sousa workings of the Três Barras deposit has been totally stripped by the hundreds of pits dug during the height of mining in this region (1968). Note the white kaolin dumps on the higher slopes, crescent-shaped series of tunnels into the colluvium, and the inselbergs, and garimpeiro shanties rising from the valley floor. Photo by Frederick H. Pough.

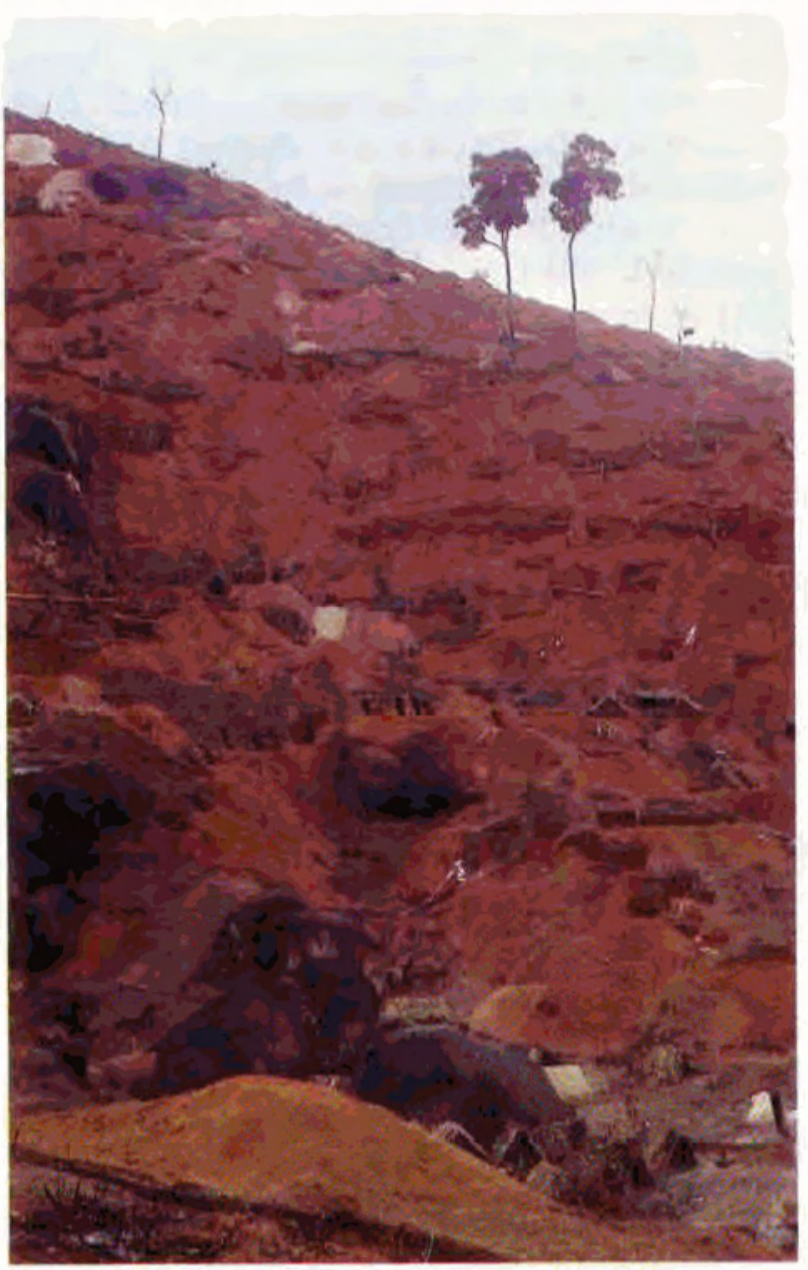




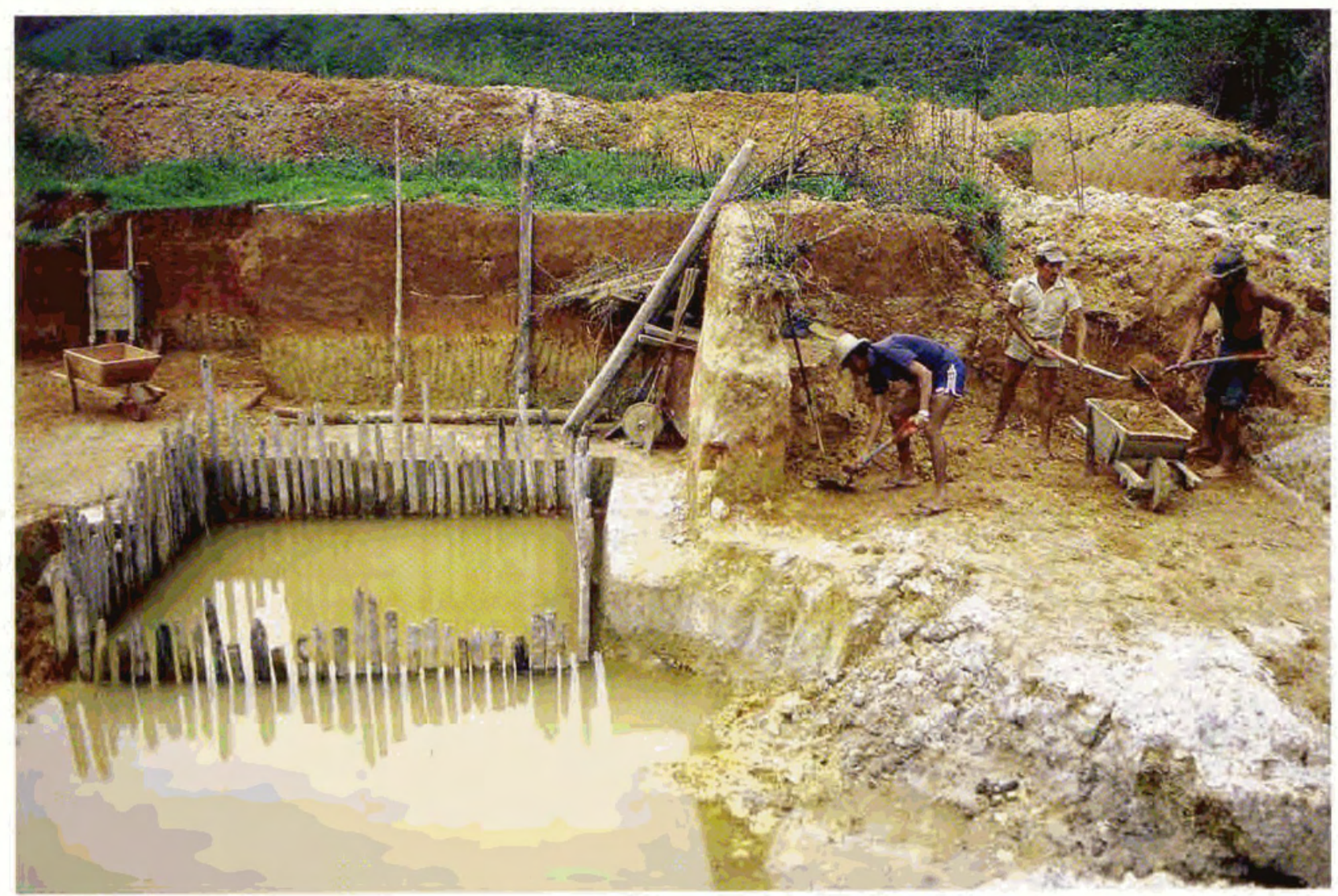

Figure 12. Working on the valley floor at Três Barras, these garimpeiros must contend with the constant flooding of their alluvial pits. Staking of the pits to avoid cave-ins is one solution. Note the layers of multicolored sand and clay, typical of alluvial deposits, in the back wall.

Três Barras Deposits. When the Pioneer mine was discovered, thousands of garimpeiros descended on the area; as was usually the case, only a few pit diggers were successful. Seven months later, in May 1968, massive deposits were discovered less than a kilometer north over the crest of the microwave hill and down the adjacent Três Barras valley. The partially worked pits below the Pioneer mine were abandoned in great haste, as the garimpeiros poured into the adjacent valley. Within a few weeks, they had set up their shanty towns on several sites-mostly on the valley floor.

Living conditions for the garimpeiros were appalling. Thousands of miners huddled in shacks with only a few huts set up to provide for their simple needs. Women and children were seldom present at this discovery (Pough, 1968).

Nevertheless, the miners attacked the 200m-high hill with such ferocity that, according to Pough, in only a few weeks the once tree-clad slopes were totally denuded, transformed into a prairie-dog village of burrows and red soil dumps; the entire steep, raw, red hillside was scarred from top to bottom, as if the excavation had been going on for years (figure 11). The two major mining areas on this small part of the cirque became known as the Lavra José de Sousa and Lavra Matto Frio.

Within 40 days of its discovery, this new find, called the Três Barras deposits, produced over $1,000 \mathrm{~kg}$ (one ton) of gem-quality crystals, albeit paler in hue and rougher in appearance than those from the nearby Pioneer mine (Pough, 1968; Rolff, 1968). These new hillside deposits extended down the valley floor to the Santa Cruz stream, and aquamarine-bearing alluvium was found several kilometers west back to and even crossing highway BR-116. Alluvial (placer) pits-cellar-like excavations that tended to fill with water-were eventually dug over the entire length of the valley. The gem-bearing gravel layer (cascalho) was found approximately $3 \mathrm{~m}$ under the valley floor, buried in many layers of multicolored clays and sands (figure 12).

A few weeks later, three miners investigating the activities of a group of vultures $3 \mathrm{~km}$ southeast of the Pioneer mine found aquamarine exposed on top of the ground where the vultures had landed. 
Within a few days, they dug over $600 \mathrm{~kg}$ of clean but pale aquamarine. The Serra do Urubu (Vulture Mountain) deposits produced over 2,000 kg of aquamarine in the next few months (Rolff, 1968; R. Nash and H. G. Kennedy, pers. comm.).

Examination of the aquamarine "crystals" found in various parts of the Três Barras deposits, from the top of the hill to the bottom of the valley several kilometers away, clearly illustrates how the physical condition of the gem specimens relates to the distance traveled from the primary pegmatite. The crystals found in the eluvial, colluvial, or (occasionally) primary deposits near the top of the hill, in conjunction with white kaolin, were etched but not worn and had good terminations (similar to the crystals pictured in this article). Crystals found in colluvial pits farther down the hill (where no kaolin showed on the dumps) were badly abraded, with pits and cracks iron stained from the red clay. Two large "crystals" (50 $\mathrm{kg}$ and $32 \mathrm{~kg}$, respectively) found on the lower slopes had no terminations and were merely broken cores of what must have been much larger crystals. The aquamarines found in the valley floor (alluvial deposits) were found with ancient river gravel; they were well worn and nearly rounded. Although these aquamarines were much less common and much smaller than those found closer to the primary deposit, the material itself was much cleaner; interestingly, the color was generally better, too (Pough, 1969; Lucio, 1980).

\section{Future Production from the Teofilo Otoni-}

Marambaia Pegmatite District. It is likely that massive deposits still remain in this region; only a small percentage of the more obvious and more easily accessible deposits have been exploited, and relatively few are being mined today (R. Nash, K. Elawar, pers. comm.). In the 1960 s, a gem dealer could purchase $3-6 \mathrm{~kg}$ of rough aquamarine per week from miners. At this writing, however, only a few grams are available to each dealer in an average week. In the last two years, the three largest pieces recovered have been only $0.9-2.9 \mathrm{~kg}$.

Unfortunately, accurate production figures, or even close estimates, for the various gemstone deposits in Brazil are impossible to obtain since the system of monetary regulation encourages the quiet movement of gemstones without official records.

The Teófilo Otoni-Marambaia pegmatite belt historically has been Brazil's major supplier of aq- uamarine. Large amounts of aquamarine may come from this area in the future, but only with the mechanized (strip) mining of the alluvium (just now beginning), since the garimpeiro population has diminished so drastically. During the author's 1983 visit to the Marambaia and Três Barras valleys, only a handful of catras were in operation.

\section{JEQUITINHONHA RIVER PEGMATITE DISTRICT}

North of the Teofilo Otoni-Marambaia pegmatite district, at Itaobim, highway BR-116 enters the Jequitinhonha River pegmatite district. The eastern and western limits of this rich aquamarine district can be reached by dirt road MG-367, and the northern limits are easily accessible and well defined by the northern villages of Salinas, Pedra Azul, and Pedra Grande (see figure 2).

Thousands of diverse pegmatites and their associated secondary deposits occur in this region. A tremendous network of creeks, streams, and rivers drains the interlaced system of valleys and basins of the Jequitinhonha River watershed, with aquamarine deposits occurring over the entire $250-\mathrm{km}$ (155 mi.) length of this pegmatite district.

The aquamarine-bearing pegmatites of this region are geochemically very similar to those of the Teofilo Otoni-Marambaia district, except that very little topaz of any type has been found here, indicating the lack of fluorine in the magmas. Also, the region overlaps with the Araçuai-Itinga green tourmaline district along the Jequitinhonha River; therefore, green and blue-green tourmalines appear in many decomposed pegmatites but always separate from any existing aquamarine deposits. Likewise, in the west near Coronel Murta and Barra de Salinas, there is some overlap with the Araçuaf-Salinas tourmaline district running due north. The Piaui valley running south from Taquaral is the source of the famous Maxixe beryls.

The earliest reported discoveries of aquamarine in this region were made by a farmer in 1903 at Ilha Alegre (Happy Island) on the banks of the Jequitinhonha River near the village of São Pedro do Jequitinhonha. Many secondary deposits have been found on low hills on both sides of the river. According to Fernandes (1905) and Oakenfull (1922), the Happy Island deposits produced many large (up to $9 \mathrm{~kg}$ ), superb aquamarines and golden beryls. As recently as 1972, this same deposit produced a $65-\mathrm{kg}$ rounded, good-quality blue-green 
specimen, which was named Cachacinha (a small shot of rum) and subsequently sold in IdarOberstein (A. Tavares and R. Nash, pers. comm.). Three other major aquamarine deposits in this district will be discussed here: Fortaleza, Medina, and Coronel Murta (the Frade mine).

Fortaleza. The city of Pedra Azul (blue stone), located $80 \mathrm{~km}$ north of Itaobim, was originally called Fortaleza because of the fortress-like inselbergs that surround it. Exceptionally clean chunks of aquamarine, some up to $12 \mathrm{~kg}$, have been produced from a nearby altered pegmatite at Laranjeiras since about 1910. Etched masses were common from this mine, but sharp crystals were never found. One of the largest, totally clean pieces was mined in 1935 and weighed $8 \mathrm{~kg}$. The lapidary firm of Oscar Machado cut three major stones from this piece: the two "smaller" stones were $293 \mathrm{ct}$ and $910 \mathrm{ct}$, respectively; the third, which was presented by the Brazilian government to U.S. President Franklin D. Roosevelt in 1937, was an incredible 1,285 ct (Calmbach, 1938). This last stone, possibly the largest cut aquamarine in existence, can be seen at the Roosevelt Museum in Hyde Park, New York. Two-kilo pieces of rough were common from this mine.

The mine itself consisted of a very large opening on a hillside, with the decomposed primary pegmatite at least $15-18 \mathrm{~m}$ wide. The mine has been inactive for many years, but attempts are now being made to reopen it. Many exceptionally clean and dark aquamarines from along the entire Jequitinhonha River valley have received the name Fortaleza in honor of their resemblance to the high-quality gems found at this locale (Sinkankas, 1974, 1981).

Medina. The village of Medina is located near a mountain range $45 \mathrm{~km}$ north of Itaobim on highway BR-116. Many secondary deposits were found in the valleys and basins of this mountain range, but most of the best aquamarines from this locale were taken from primary deposits still encased in the host gneisses of these mountains. Hundreds of tunnels (adits) have been sunk attempting to reach the primary pegmatites, and dozens of workings were very successful, producing much of the finest quality aquamarine to come from Brazil in recent years (again, see figure 1). Mining conditions and terrain are similar to those of the Frade mine discussed below. Almost no aquamarine is found in

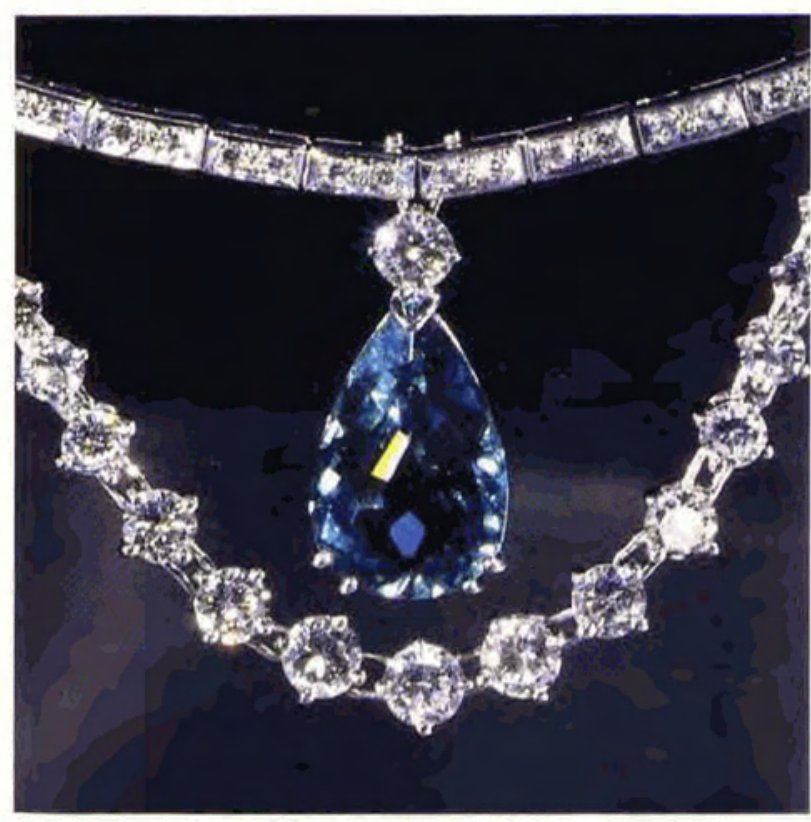

Figure 13. One of the small (approximately $5 \mathrm{ct}$ ) but superb Coronel Murta aquamarines. Photo (C) Harold e) Erica Van Pelt; courtesy of Jules Sauer (Sauer, 1982).

Medina now, although 3,000 ct from this deposit were produced in October 1983.

To the author's knowledge, the largest, most intense faceted Medina aquamarine is an octagonal 107-ct stone in the collection of Kalil Elawar in Teoffilo Otoni; the 7.9-kg crystal from which this stone was cut in 1978 yielded a total of 8,000 ct of fine gems (K. Elawar, pers. comm.).

Coronel Murta (Frade mine). The city of Coronel Murta, on the banks of the Jequitinhonha River, was founded around 1830 by a retired colonel of that name. Within $6 \mathrm{~km}$ of the city by road is a prominent inselberg that is visible from a great distance. As one approaches Coronel Murta from Araçuar, the back side of the inselberg looks like a giant reclining friar with a fat belly. When colluvial and primary deposits were discovered at the base of the inselberg early in 1973, the mine was given the name Mina do Frade (Friar mine). Few people in the trade have heard of Frade mine aquamarine, but nearly everyone has marveled at the small but stunning blue stones known simply as Coronel Murta; they are one and the same (figure 13).

In 1973, Inacio Moura Murta, a great-great grandson of the founding colonel, led a group of 
five garimpeiros to dig in the red soil on Murta's property where aquamarine had been found. These diggings were begun in a north-south valley 1,200 $\mathrm{m}$ long that rises gradually for $750 \mathrm{~m}$ and then, abruptly, becomes very steep for the last $450 \mathrm{~m}$, peaking on a hill overlooking the city of Colonel Murta only a hundred meters to the west of the giant Frade inselberg (figure 14).

The first valley-floor diggings, some as deep as 3-4 m, exposed only loose crystals in the red soil of the colluvial deposit (again, see figure 6). But within a few months, an expanded garimpeiro work force of more than a hundred men enthusiastically extended their pits and tunnels over literally half the valley, up the slopes of the hills. In the higher regions, after digging only a meter or so into the colluvial soil, they began to strike the primary pegmatite wall, which had been intruded into the east side of the valley for what appeared to be at least $750 \mathrm{~m}$ in a north-south direction (figure 15). This was the pegmatite that had sloughed off

Figure 14. The mine shack and main tunnel at Frade mine are only a short distance from the inselberg after which the area is named.

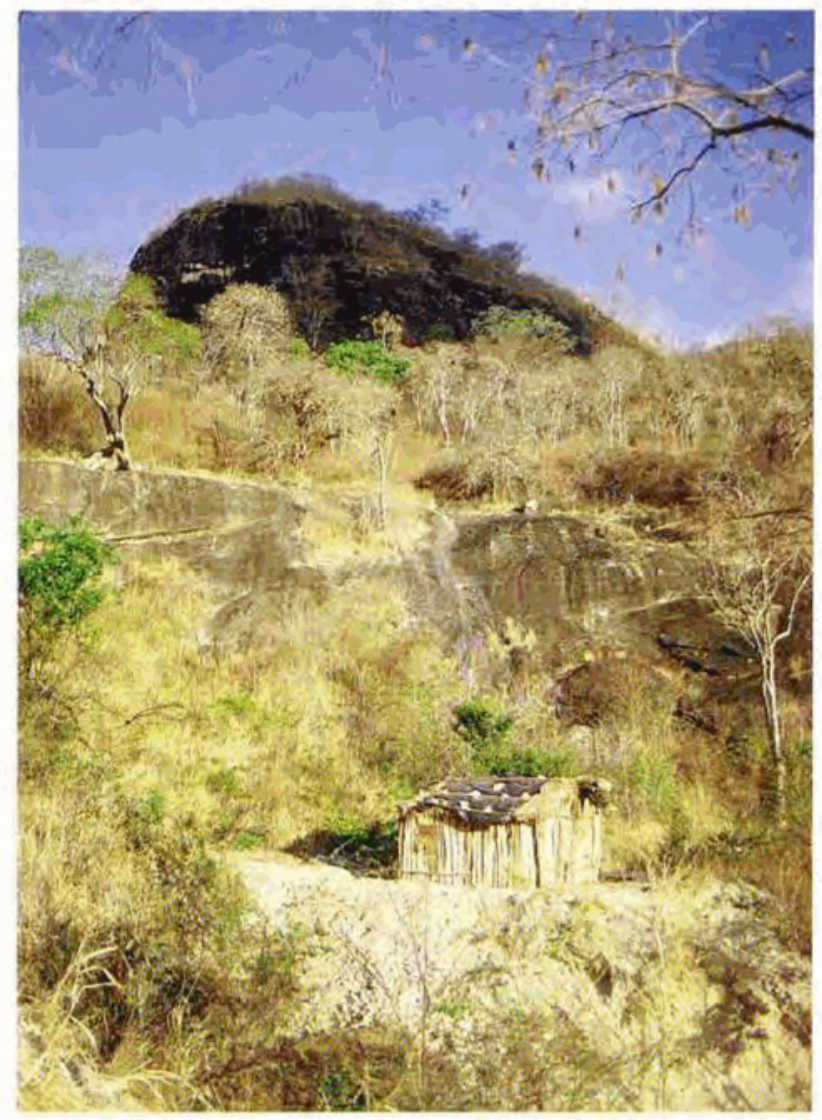

its crystals as the hill eroded away, forming the lower colluvial deposits.

During 1974, the garimpeiros began attacking large outcrops of this pegmatite even higher on the hill by digging large caves (figure 16). Later that same year, they started a labyrinthine series of tunnels in the primary pegmatite $120 \mathrm{~m}$ below the top of the ridge at the far north end of the valley. These tunnels extended deep inside the mountain, entering only $30 \mathrm{~m}$ from the main mine shack. In this tunnel system, the pegmatite vein has been cleaned out completely for $60 \mathrm{~m}$ inside the mountain, leaving nothing but the schist wall rock and some support pillars.

As the miners tunneled deeper into the hillside, the direction of the veins indicated that the pegmatite might continue straight through the hill with an outcrop on the opposite side. Although exploration in this new area revealed no outcrop where the garimpeiros had hoped to find it, in the course of their preliminary digging they discovered extensive crystal deposits in the eluvium directly on top of the hill. Eventually, colluvial deposits were discovered extending at least $150 \mathrm{~m}$ down the hillside facing Coronel Murta village. Again, in some locations, after digging down only a meter or so, they encountered the primary pegmatite. It seems, then, that the pegmatite they had been working on $120 \mathrm{~m}$ below had been intruded clear through the top of the hill; and as the hill eroded away, it had shed its crystals down the slope.

A monumental excavation project began, and eventually the entire top of the hill was pitted, dug up, and turned over repeatedly, until the area resembled an artillery range. In the process, though, thousands of crystals were found.

Occurrence. This pegmatite is unusual for its long, narrow shape. Mineralogically, however, it is typical of other deposits in this district. Specifically, black tourmaline is abundant, as are small plates of biotite mica, big smoky quartz crystals, and approximately $25-\mathrm{cm}$ unaltered feldspar crystals |reflecting the unaltered state of the primary pegmatite body). In fact, hundreds of tons of fine feldspar lie on the dumps, unsalable, because of the $450-\mathrm{km}$ distance to the marketplace in Governador Valadares. The Frade mine, like most in the Araçuai-Salinas-Itinga region, has to meet expenses strictly through the sale of gem rough.

There were two unusual occurrences at this time, however. First is the presence of green mi- 


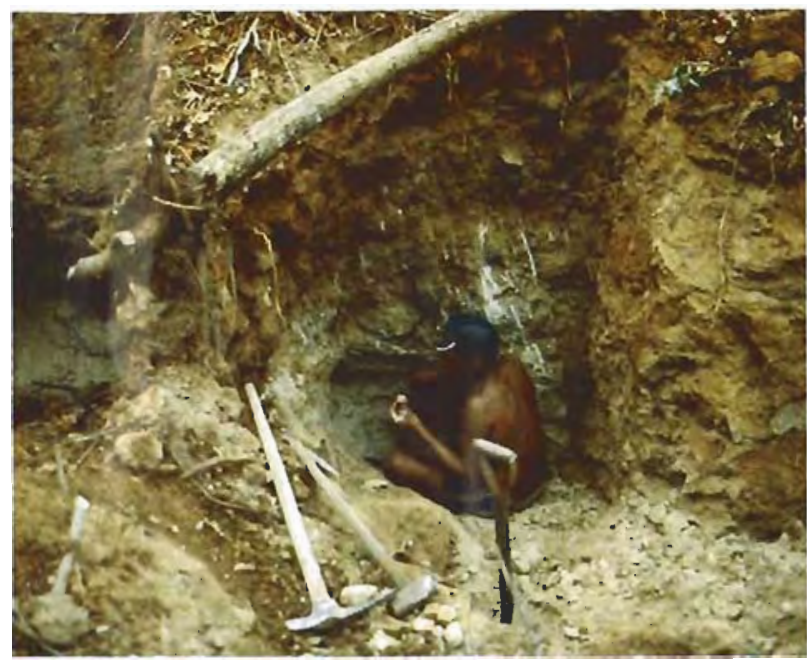

Figure 15. After only a meter of tunneling, this garimpeiro has reached the primary pegmatite (note the white feldspar) at Frade.

crocline (amazonite), which was common andalong with black tourmaline-was the best indicator that gem aquamarine was close by. Second, a few gem crystals of rose tourmaline, some as long as $4 \mathrm{~cm}$, were found in the main tunnel. The lithium, and manganese required to produce rose tourmaline are seldom found associated with aquamarine. No topaz or kunzite was found.

Current and Future Production. When the Frade mine reached its peak production in 1981, the 200 $\mathrm{kg}$ of aquamarine recovered meant an average of only one kilo per garimpeiro. All of the crystals were highly fractured; $70-80 \%$ of the pieces weighed less than $100 \mathrm{~g}$ ( 3 ozs.). The highest quality aquamarine was found in pockets in the pegmatite. The largest piece of rough weighed a little over $260 \mathrm{~g}$; the largest intact (but internally fractured $)$ crystal was only $7.6 \times 3.8 \mathrm{~cm}\left(3 \times 1^{1 / 2}\right.$ in.). These production figures contrast sharply with those from Três Barras, although the best Coronel Murta color is far better than the best Três Barras color.

In fact, the best aquamarine from this mine is among the finest in Brazil. Yet, because the crystals are so fractured, intense faceted stones are usually less than $1 \mathrm{ct}$, although totally clean stones as large as $4-5 \mathrm{ct}$ do exist and 3-ct stones are not uncommon. Ten-carat stones have been faceted but they are not completely clean.

Production has dropped off sharply in the last three years, and only 70 garimpeiros work the Frade mine today. The mine owners insist that there will be considerable future production be-

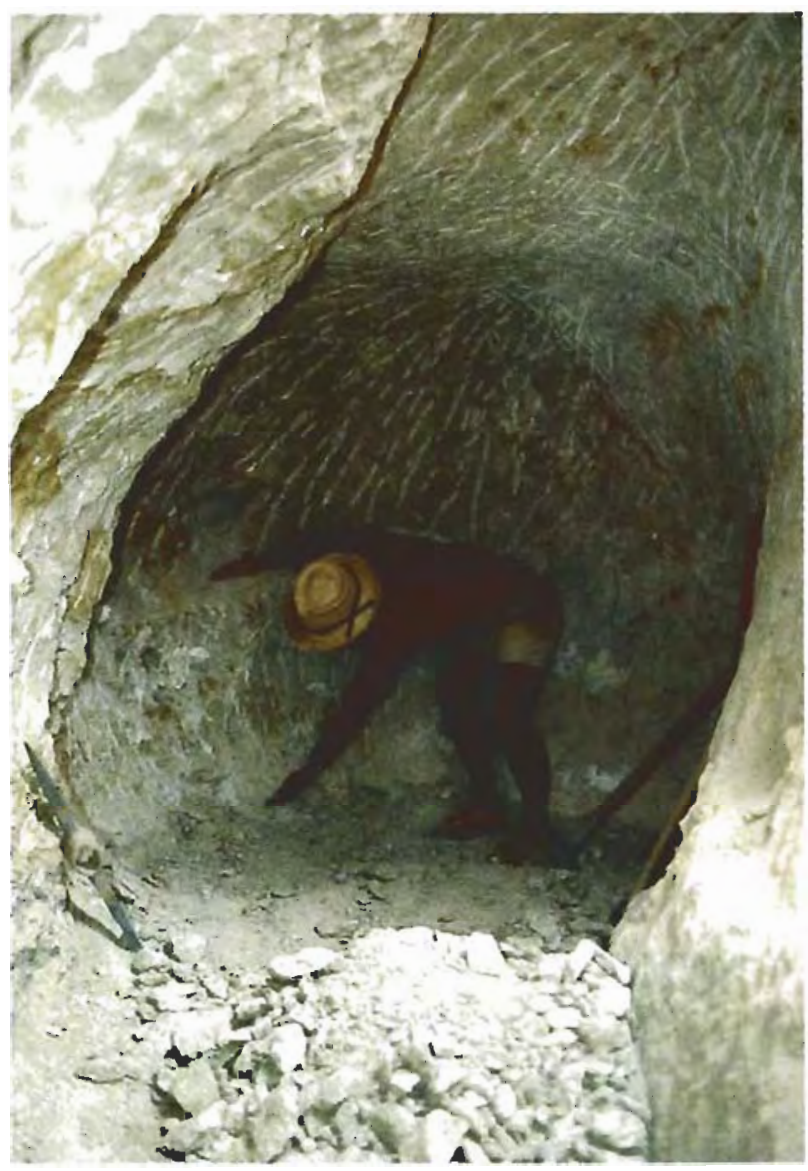

Figure 16. This garimpeiro is indicating the width of the pegmatite body in one of the large caves excavated on the upper slopes of Frade mountain.

cause there are additional "virgin" areas of the pegmatite and colluvial deposits still to be exploited; however, the extent of the reserves is speculative. Because of the expense of hard-rock mining, the shortage of manpower, and the unproved reserves, it is the author's belief that this unusual occurrence will continue to produce only very small quantities of fine aquamarine in the years to come. Although hundreds of alluvial pits have been dug near Coronel Murta, as might be expected they have produced only a fraction of the material found in the primary deposit.

\section{OTHER AQUAMARINE DEPOSITS}

The Araçuai River-Capelinha-Malacacheta District. Along the Araçuar River on the north and its tributaries on the south, in the area enclosed by the cities Minas Novas, Turmalina, Capelinha, Malacacheta, Novo Cruzeiro, and Lufa, hundreds of valleys and basins have yielded notable primary and secondary aquamarine-bearing deposits (Calmbach, 1938; Sinkankas, 1974, 1981; Pecora 
Figure 17. This 6-cm heliodor (golden beryl) from near Colatina, E.S., accompanied by a 40.4-ct faceted mate, is representative of some of the fine material that has been found in the area around northeastern Minas

Gerais. Photo (C) Harold et) Erica Van Pelt.
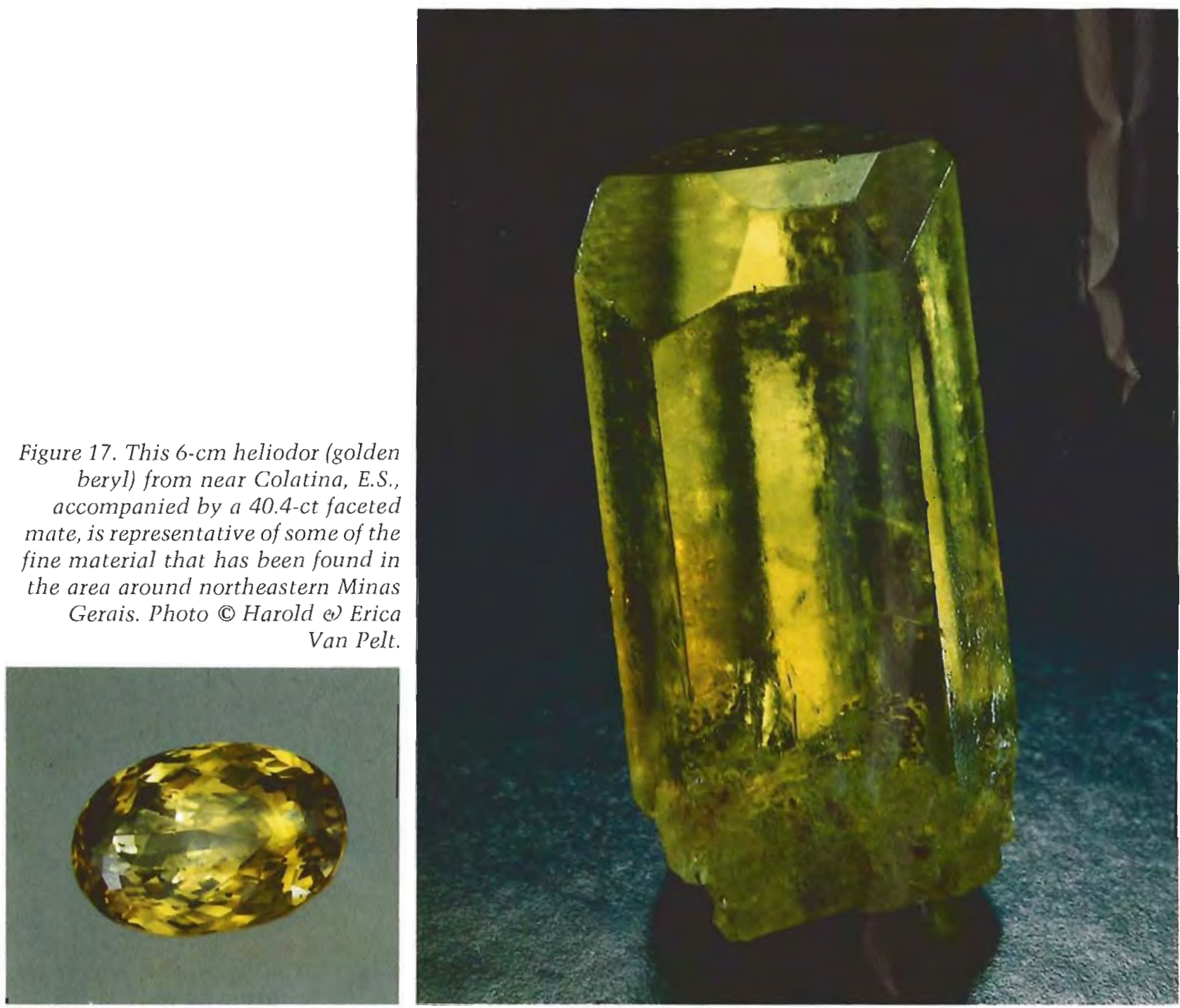

et al., 1950). Additionally, deposits of both gem beryl and tourmaline have been found in the northernmost portion of the three rivers Gravatá, Setúbal, and Sucuriú and of the larger river Araçuaí (to the city of Araçuar), as early as the 1890s (Sinkankas, 1974). The countryside surrounding virtually all of the cities in the areas shaded in blue on the map in figure 2 has produced significant quantities of gem-quality aquamarine.

Governador Valadares District. One of the most productive regions of Minas Gerais in both volume of gem beryl and size of crystals is the area within a $150-\mathrm{km}(90 \mathrm{mi}$.) radius of Governador Valadares and embracing the watershed of the Doce and Suaçui Grande rivers. The countryside surrounding all of the cities in this area on the map in figure 2 has produced major finds in both primary and secondary deposits (Calmbach, 1938; Sinkankas, 1974, 1981).

Three of the largest single aquamarine crystals ever recovered were found in the Governador Valadares region: a $108 \mathrm{~kg}$ piece at Ariranho on the Rio Bugre, in 1942 (Ball, 1943); a 25.4-kg piece near Resplendor, in 1946 (Sinkankas, 1974), and a particularly fine 61-kg specimen (called the Lucia) found in gravels at Garajaú, in 1955 (Abreu, 1965; Sinkankas, 1974).

The quality of the aquamarine varies throughout Minas Gerais, but most of the gem rough found is pale to medium blue-green (heat treated to produce a comparable intensity of purer blue). One advantage of this gem is that large $(15+\mathrm{ct})$, totally clean stones are readily available.

Currently, this region is producing only small amounts of aquamarine. There continues to be 
great potential, however; the strip mining of alluvial deposits in the Teofilo Otoni-Marambaia region, in particular, holds promise for significant future production. Judging from the past, major deposits could be found in the vicinity of any of the cities in figure 2 .

\section{HELIODOR (GOLDEN OR YELLOW BERYL)}

Top-quality golden or yellow beryl (figure 17) is much rarer than aquamarine, although the best heliodor is not as valuable as the best aquamarine. Some yellow and golden beryls, when heat treated for $1-12$ hours to between $280^{\circ} \mathrm{C}$ and $600^{\circ} \mathrm{C}$ (depending on the source of the material and the inclusions|, will turn a pleasing, more salable aquamarine color (no greater in intensity than the original yellow or gold); others, however, will just become a lighter yellow. Still others may also turn such a pale blue that they are worth much more left as heliodor. One can be sure that the best golden or yellow stones offered for sale have not been heat treated-but that others from the same crystal were undoubtedly tested.

Heliodor usually occurs mixed with bluish and greenishiberyls as a small portion of the total deposit. The author knows of only one mine where heliodor. constituted a large percentage of total beryls produced: Mina Urubu, near the city of Santa Cruz immediately east of Novo Cruzeiro. Yellow and golden beryls have also been found in significant amounts at the Marambaia, Medina, Ilha Alegra, and Farrancho deposits, with notable production also from Bom Jesus do Lufa, Dois de Abril, Guanhães, Joaĩma, Minas Novas, Sabinópolis, Serro, and Sapucaia as well. Quality gems, however, are always in short supply, especially large stones.

The world's largest cut heliodor, at 2,054 ct, is in the Gem Hall at the Smithsonian Institution, Washington, D.C. (illustrated in Sinkankas, 1981).

\section{MORGANITE (PINK BERYL)}

Morganite, the popular rose-pink variety of beryl, is also rarer than aquamarine. Morganite occurs commonly in two "Iess desirable" color phases: peach and salmon. Generally, the rose-pink tints are more fashionable. Cut morganites are commonly heated individually in a test tube over an alcohol flame $\left(200^{\circ}-400^{\circ} \mathrm{C}\right)$ for a few minutes to obtain a delicate pink hue (which is totally stable). As with aquamarine, virtually all morganite is heated by this process, which essentially dupli- cates the geothermal processes that produce the rose-colored stones occasionally found in nature.

The largest deposit of morganite crystals ever found occurred at the Corrego do Urucum mine in Galileia in 1973. Approximately 300 crystals, some weighing as much as $10 \mathrm{~kg}$ (22 lbs.), were discovered lining the walls of an immense cylindrical pocket. This deposit will be discussed in greater detail in the upcoming article dealing with kunzite, which was also found in great quantity at this locality.

Other significant deposits of morganite in Brazil were all found in Minas Gerais. These include Sapucaia (municipality of Galileia), Calisto, Minas Novas, and along the Jequitinhonha River valley. No production is currently coming from any of these localities. Occasional kilograms of material, however, have been found recently at the Salinas mine and at an unnamed deposit near Conselheiro Pena, which produced some 5,000 ct in 1982 from a single pocket. This rose-pink gemstone is in chronic short supply; no major deposit has been discovered since 1973.

To the author's knowledge, the two best faceted Brazilian morganites are both at the Smithsonian Institution: $236 \mathrm{ct}$ and $250 \mathrm{ct}$ (Desautels, 1965, photo on p. 38; Desautels, 1979, photo on p. 39).

\section{SUMMARY AND CONCLUSION}

Aquamarine is found over most of the northeastern part of Minas Gerais; millions of carats have been mined since the discovery of the Papamel crystal in 1910. Both heliodor and morganite are significantly less common. Aquamarine is usually heat treated to obtain its optimum blue; heliodor may be heat treated to turn from yellow to aquamarine blue; peach- and salmon-colored morganites are often heat treated to obtain the preferred rose-pink color.

Most of the aquamarine is found in secondary deposits, although much of the darkest material has come from the primary pegmatites at Fortaleza, Medina, and Frade (Coronel Murta). Currently, little aquamarine (or heliodor or morganite) is being produced because of the shortage of garimpeiro labor and the expenses involved in mining, although small amounts are coming from other states in Brazil. Nevertheless, there continues to be great potential for the discovery of major deposits anywhere in the Minas Gerais pegmatite area. 


\section{REFERENCES}

Abreu S.F. de (1937) A riqueza mineral do Brasil. S.L. Bibliografia Pedagogica Brasileira, Vol. 102.

Abreu S.F. de (1965) Recursos Minerais do Brasil. Minerais não metálicos. Instituto Brasileiro de Geográfica e Estatística, Conselho Nacional de Geografia, Publication \#20, Rio de Janeiro.

Anderson M. (1978) Brazil-nature's mineral treasure chest. Lapidary Joumal, Vol. 31, No. 11, pp. 2302-2312.

Ball S.H. (1930) Historical notes on gem mining. Economic Geology, Vol. 26., pp. 68l-738.

Ball S.H. (1943) Gem stones. U.S. Bureau of Mines and Minerals Yearbook, Washington, DC, pp. 1509-1520.

Bank H. (1973) From the World of Gemstones. UmschauVerlag, Frankfurt am Main.

Bank H. (1979) Edelsteine aus Brasilien. Zeitschrift der Deutschen Gemmologischen Gesellschaft, Vol. 28, No. 1, pp. 21-34.

Bassett A.M. (1967) Understanding Brazilian geology helps. Lapidary Journal, Vol. 21, No. 2, pp. 306-311.

Bastos F.M. (1964) A 15.4-pound Brazilian aquamarine. Gems (4) Gemology, Vol. 11, No. 8, pp. 239-24l.

Bastos F.M. (1972) Brazil: land of tourmalines. Lapidary Journal, Vol. 26, No, 8, pp. $1224-1229$.

Bastos F.M. (1981) Emeralds from Itabira, Minas Gerais, Brazil. Lapidary lournal, Vol. 35, No. 9, pp. 1842-1848.

Burns E.B. (1965) A Documentary History of Brazil. Alfred A. Knopf, New York.

Calmbach W.F. (1938) Handbuch Brasilianischer Edelsteine und ihrer Vorkommen. N. Medawar, Rio de Janeiro.

Calógeras J.P. (1904) As minas do Brasil e sua legislaçāo. Imprenso Nacional, Rio de Janeiro.

Cameron E.M., Jahns R.H., McNair A.M., Page L.R. (1949) Internal Structure of Granitic Pegmatites. Economic Geology, Monograph 2, p. 115.

Caplan A., Wilson W. (1980) Interview: Allan Caplan. Mineralogical Record, Vol. 11, No. 6, pp. 351-366.

Cassedanne J.P., Lowell J. (1982) Famous mineral localities: the Virgem da Lapa pegmatites. Mineralogical Record, Vol. 13, No. 1, pp. 19-28.

Dana E.S., revised by Hurlbut C.S. Jr. (1959) Manual of Mineralogy, 17 th ed. Wiley \& Sons, New York.

Desautels P.E. (1965) Gems in the Smithsonian Institution. Smithsonian Institution Press, Washington, D.C.

Desautels P.E. (1970) The Mineral Kingdom. Madison Square Press, New York.

Desautels P.E. (1979) The Gem Collection: Treasures in the Smithsonian. Smithsonian Institution Press, Washington, D.C.

Dirac F., Ebert H. (1967) Isotopic age from the pegmatite provinces of Eastern Brazil. Nature, Vol. 215, pp. 948-949.

Dreher O. (1912) Grosser Aquamarine krystall aus Brasilien. Centralblatt für Mineralogie, Vol. 11, p. 338.

Eschwege W.L. (1833) Pluto Brasiliensis. G. Reimer, Berlin.

Fernandes X.P. (1905) Aquamarines and tourmalines at Arassuahy in Minas Gerais. Brazilian Engineering and Mining Review, Vol. 2, No. 3, p. 42.

Ferraz L.C. (1929) Compendio dos Mineraes do Brasilen Forma de Diccionari. Imprensa Nacional, Rio de Janciro.

Freyberg, B.V. (1934) Die Bodenschatage des States Minas Gerais, Brasilien. Schweizerbart, Stuttgart.

Gaines R.V. (1976) Beryl-a review. Mineralogical Record, Vol. 7, No. 5, pp. $211-223$.

Gesner C. (1565) De Rerum Fossilium, lapidum et gemmarum. Gesner, Tiguri.

Gonsalves A.D. (1949) As Pedras Preciosas na Economiz Na cional. Gráfica Olimpica Editora, Rio de Janeiro.

Hahn M. (1955) Edelsteine und P'erlen, in Schmuck und Edelsteine, E. Schöndorff, Munich.

Jahns R.H. (1982) Internal evolution of granitic pegmatites. In Granitic Pegmatites in Science and Industry, P. Cerný, Ed., Mineralogical Association of Canada, Winnipeg.

Kunz G.F. (1911) Precious stones. In, The Mineral Industry During 1910, Vol. 19, p. 27.

Lucio A. (1980) Review of history and survey of present and future mining in Brazil. Report at the 7th Annual Rochester Mineralogical Symposium, Rochester, New York (unpublished).

Mawe J. (1812) Travels in the Interior of Brazil. Longman, Hurst, Rees, Onme, and Brown, London.

Moore P.B. (1973) Pegmatite phosphates: a descriptive mineralogy and crystal chemistry. Mineralogical Record, Vol. 4, No. 3, pp. 103-130.

Moura O.J.M. de (1981) Gems from Brazil. In Metamig, Metais de Minas Gerais, S.A., Belo Horizonte.

Oakenfull J.C. (1913) Brazil in 1912. Robert Atkinson, London.

Oakenfull J.C. (1922) Brazil: A Centenary of Independence, 1822-1922. C.A. Wagner, Freiberg.

O'Leary O.J. (1970) Locality-Minas Gerais, Brazil. Mineralogical Record, Vol. 1, p. 73.

Paiva G. de (1946) Provincias pegmatíticos do Brasil. Departamente Nacional da Produção Mineral Divisão Fomento da Producāo Mineral, Vol. 78, pp. 13-21.

Pecora W.T., Klepper M.R., Larrabee D.M., de Barbosa A.L. Frayha R. (1950) Mica deposits in Minas Gerais, Brazil: geologic investigation in the American Republics, 1949. U.S. Geological Survey Bulletin, 964-C, pp. 205-305.

Pough F.H. (1968) The Tres Barras aquamarine mine. Lapidary Joumal, Vol. 22, No. 8, pp. 1038-1042.

Pough F.H. (1969) Brazil and its minerals. Mineral Digest, Vol. 1, No. 1, pp. 25-32.

Rolff A. (1968) The aquamarine-bearing regions of Brazil. Lapidary Journal, Vol. 22, No. 8, pp. 1044-1049.

Sauer J.R. (1982) Brazil, Paradise of Gemstones. Rio de Janeiro.

Shigley J., Kampf A. (1984) Gem-bearing pegmatites: a review. Gems \&) Gemology, Vol. 20, No. 2, pp. 64-77.

Sinkankas J. (1964) Mineralogy for Amateurs. D. Van Nostrand Co., Toronto.

Sinkankas J. (1974) Beryl in Brazil, Parts I-III. Lapidary Journal, Vol. 28, Nos. 2-4, pp. 324-332; 506-515; 646-655.

Sinkankas J. (1981) Emerald and Other Beryls. Chilton Book Co., Radnor, PA.

Souza A.J.A. de (1943) Aspectos da economia da pedras preciosas. Mineraçāo e Metalurgia, Vol. 7, No. 36, pp. 257-262.

Zeitner J.C. (1979) Gems of Brazil. Lapidary Journal, Vol. 33, No. 1, pp. $142-155$. 